\title{
EXTENDING THE FIREMAN'S RULE TO GREAT BRITAIN: PROTECTING BRITISH CITIZENS FROM TORT LIABILITY FOR FIREFIGHTERS' LINE-OF-DUTY INJURIES
}

\section{INTRODUCTION}

No one can reasonably argue that firefighting is not a career filled with hazards. ${ }^{1}$ The men and women who serve our communities as firefighters routinely face such perils as structural collapse, burns, smoke inhalation, and heat exposure injuries. Considering the hazardous nature of the profession, firefighters will inevitably be injured while on duty. Naturally, firefighters will seek compensation for these line-of-duty injuries.

This note analyzes the methods that are appropriate to achieve the dual ends of compensating firefighters and avoiding the overburdening of citizens who call upon fire services for help. As will be discussed at length, the United States and Great Britain approach this compensatory dilemma from opposite directions. In Great Britain, tort law is applied to negligent landowners whose actions result in injuries to firefighters in the same manner that tort law is applied to any other British tortfeasor. The United States, on the other hand, generally denies firefighters recovery in tort for injuries caused by the actions of negligent landowners. The United States bases its denial of recovery upon the doctrine that has become known as the Fireman's Rule. ${ }^{2}$ As will be demonstrated, the Fireman's Rule provides a more just and efficient approach to tort liability for firefighters than does the system used in Great Britain. To achieve the highest level of fairness and efficiency with respect to both British firefighters and British citizens, Great Britain should adopt the Fireman's Rule as it exists in the United States.

What is the Fireman's Rule?" "The classic formulation of the rule

1. The National Fire Protection Association (NFPA) reported that there were 95,400 firefighters injured while on duty in 1994, and of that total, 52,875 of the injuries occurred to firefighters while on the fire scene. NFPA, NFPA Fire Facts: U.S. Fire Loss Statistics for 1994 (visited Nov. 16, 1997) < http://www.theskanner.com/special/special96/fire/fe13.sht $\mathrm{ml}>$. Additionally, the United States Fire Administration reports that 94 firefighters died while on duty in 1996. United States Fire Admin., National Fire Programs: Firefighter Fatalities in the United States in 1996 (visited Nov. 16, 1997) <http://www.usfa.fema.gov/ nfde/ff_fat.htm >. The report did, however, indicate that "[t]he overall trend in firefighter fatalities is down $35 \%$ over the last 10 years" with deaths during that interval ranging from a high in 1978 of 171 deaths to a low of 75 deaths in 1992 . Id.

2. The Rule may also be called the Firefighter's Rule, the Professional Rescuer Doctrine, or other variations of these names. However, because the Rule is traditionally called the Fireman's Rule, that is the name that will appear throughout this note.

3. While the term "Fireman's Rule" only mentions firefighters, the Rule also applies to police officers. Arguably, other occupations could also be subject to the Fireman's Rule. For example, the veterinarian who is bitten by a dog could logically be placed within the Fireman's Rule, because the hazard of being bitten is inherent when working with animals. 
holds that 'negligence in causing a fire furnishes no basis for liability to a professional fireman injured [while] fighting the fire.' ${ }^{\prime 4}$ The Fireman's Rule is also defined as the "[d]octrine which holds that professionals, whose occupations by nature expose them to particular risks, may not hold another negligent for creating the situation to which they respond in their professional capacity." firefighters and police officers will not be able to recover in tort for injuries resulting from the negligent conduct requiring their response.

The British legal system has been steadfastly opposed to the Fireman's Rule. Indeed, at least one British judge has gone so far as to say that "the American 'fireman's rule' has no place in English law." British courts think it illogical to place firefighters and police officers at a "disadvantage" in recovering for the negligence of others simply because they have taken it upon themselves to protect lives and property. Instead, British courts find recovery by firefighters and police officers compelling because the presence of firefighters and police officers is foreseeable in circumstances of emergency. In light of this sharp contrast between the British and American systems, it is important to understand the bases for the American and British rules regarding firefighters' ability to recover in tort.

This note considers the advantages to both the British justice system and British citizens should Great Britain adopt the Fireman's Rule. Through a discussion of firefighters' status as sui generis entrants of land, ${ }^{7}$ the doctrine of assumption of risk, and economic efficiency, this note demonstrates that the application of the Fireman's Rule in Great Britain is not only just, but also essential to maintaining the integrity of the British torts

Since the veterinarian is not publicly employed, however, he is barred from recovery by what may simply be called assumption of risk. See Carter v. Taylor Diving and Salvage Co., 341 F. Supp. 628 (E.D. La. 1972), aff'd, 470 F.2d 995 (5th Cir. 1973) (denying recovery to doctor employed to render emergency services).

But cf. Solgaard v. Guy F. Atkinson Co., 491 P.2d 821 (Cal. 1971) (allowing recovery by a doctor who, after being hired by the company to render medical services, was injured executing this task in a trench rescue). In refusing to apply the Fireman's Rule, the court noted that "[i]t is not . . . a doctor's business to cope with steep, slippery embankments. Plaintiff agreed only to furnish medical aid to injured employees; he did not further agree to expose himself to risks and hazards not necessarily inherent in the performance of his services." Id. at 825-26. See also Kowalski v. Gratopp, 442 N.W.2d 682 (Mich. Ct. App. 1989) (holding that the Fireman's Rule must be limited to public employees).

4. Seibert Sec. Serv., Inc. v. Migailo, 22 Cal. Rptr. 2d 514, 518 (Cal. Ct. App. 1993) (quoting Walters v. Sloan, 571 P.2d 609 (Cal. 1977)).

5. BLACK'S LAW DICTIONARY 438 (6th ed. 1991).

6. Ogwo v. Taylor [1987] 3 All E.R. 961,966 (H.L.) (Bridge, L.J.).

7. Sui generis means "of its own class." The reason firefighters are considered members of their own class is because they do not fit neatly within traditional land entrant categories, i.e., invitees and licensees. For a discussion of firefighters and land entrant categories, including sui generis, see infra Part III.A. 
system. Additionally, application of the Fireman's Rule in Great Britain would relieve British citizens of the injustice of having to compensate firefighters in tort simply for making firefighters do their jobs.

Part II discusses the Fireman's Rule in the United States and acquaints the reader with some of the specific foundations of the Rule. This part traces the origin of the Fireman's Rule in the United States by discussing the seminal case of Gibson $v$. Leonard. ${ }^{8}$ After this discussion, the next major case, Walters $v$. Sloan, is examined. ${ }^{9}$ Although the court in Walters ruled in favor of the Fireman's Rule, this case is sometimes cited by opponents of the Fireman's Rule. ${ }^{10}$ Opponents of the Rule find Walters persuasive because Justice Tobriner's dissenting opinion criticizes the Rule exhaustively. In fact, at least one British opinion has cited Justice Tobriner's dissenting opinion as persuasive authority. The last case discussed is Krauth v. Geller. ${ }^{11}$ Justice Weintraub's opinion for the majority in Krauth thoroughly analyzes the bases for applying the Rule.

Part III analyzes the three bases for the Fireman's Rule: assumption of risk, the sui generis status of firefighters, and economic efficiency. The theories set forth in this section form the basis for application of the Fireman's Rule in the United States. The material discussed is essential to an understanding of the implications of extending the Fireman's Rule to Great Britain.

Part IV examines the British law of occupiers' liability toward firefighters. This part explains the foundation of Great Britain's refusal to adopt the Rule. First, this part discusses Great Britain's Occupiers' Liability Act $1957,{ }^{12}$ which abrogated status distinctions between entrants of land. The legislative history and the text of the Act are also examined..$^{13}$ The text of the Act and its application, or lack thereof, by British courts is interesting since three sections of the Act clearly bar recovery by firefighters. ${ }^{14} \mathrm{Next}$, this part discusses Great Britain's failure to adopt the Fireman's Rule. By analyzing British case law, this part examines the courts' reasoning in recent as well as older cases that refused to apply the Rule. In addition to the

8. 32 N.E. 182 (III. 1892).

9. 571 P.2d 609 (Cal. 1977).

10. Opponents of the Rule find Walters persuasive because Justice Tobriner's dissenting opinion criticizes the Rule exhaustively. In fact, at least one British opinion has cited to Justice Tobriner's dissenting opinion as persuasive authority. See generally Ogwo v. Taylor [1987] 3 All E.R. 961, 966 (H.L.). For a critical analysis of Justice Tobriner's conclusions, see infra Part III.C.2.

11. 157 A.2d 129 (N.J. 1960).

12. Occupiers' Liability Act, 1957, 5 \& 6 Eliz. 2, ch. 31 (Eng.) [hereinafter Occupiers' Liability Act 1957].

13. A critical review of the Act's wording, however, is reserved for Part IV.A.

14. Occupiers' Liability Act 1957, supra note 12, §\$2(3)(b), 2(4)(a), 2(5). 
British cases, Justice Tobriner's dissenting opinion in Walters is explored and criticized.

Finally, Part V reanalyzes and reinterprets the British cases discussed in Part IV by applying to them the American tort principles discussed in Part III. This section demonstrates that application of the Fireman's Rule in Great Britain is both workable and desirable.

\section{THE FIREMAN'S RULE IN THE UNITED STATES}

The Fireman's Rule took root in American jurisprudence over a century ago. ${ }^{15}$ In the landmark decision of Gibson $v$. Leonard, the Supreme Court of .Illinois barred a firefighter from recovering in tort against a landowner for injuries he suffered in an elevator while fighting a fire on the defendant's premises. ${ }^{16}$ The court held that the firefighter entered the premises as "a mere naked licensee" and thus had no greater rights than any other licensee. ${ }^{17}$ The only duty owed to the firefighter was that the owner refrain from "willful or affirmative acts which [were] injurious." 18 The court concluded that, because the landowner was under no duty to maintain his premises in a safe condition for firefighters, the firefighter in that case could not recover for injuries resulting from the dangerous condition of an elevator. ${ }^{19}$ An important factor considered by the court was that firefighters

15. The Fireman's Rule has not received unanimous support even in America. Four states have abolished their respective versions of the Fireman's Rule. Minnesota abolished its version of the Fireman's Rule in MINN. STAT. $\$ 604.06$ (1988); Oregon in Christenson v. Murphy, 678 P.2d 1210 (Or. 1984); Florida in FLA. STAT. ch. 112.182 (1995); and Colorado in Rhea v. Green, 476 P.2d 760 (Colo. Ct. App. 1970) (implicitly rejecting the Fireman's Rule), in Banyai v. Arruda, 799 P.2d 441 (Colo. Ct. App. 1990) (explicitly rejecting the Fireman's Rule), and in Wills v. Bath Excavating, 829 P.2d 405 (Colo. Ct. App. 1991) (following the Banyai decision). Note that some Minnesota and Florida cases are used in this discussion. Even though these cases have been abrogated by statute, they are still useful to determine how the Fireman's Rule would apply in jurisdictions still following the Rule.

Indiana may be on the threshold of either overruling or limiting the Rule. See generally Johnson v. Mark Stefan, No. 49A02-9508-CV-449 (Ind. Ct. App. Sept. 30, 1997), cited and summarized in Court Summaries \& Trial Reports, IND. LAW., Oct. 29, 1997, at 6A [hereinafter Court Summaries]. The Johnson court, referring to Heck v. Robey, 659 N.E.2d 498 (Ind. 1995) (discussing the Fireman's Rule), held that "if a public safety officer is injured as a result of another's negligence, the Firem[an's] Rule will not categorically protect the negligent party merely because the public safety officer was engaged in his employment." Court Summaries, supra, at 6A. The tone of the Johnson opinion indicates that, at most, the Rule only will be applied to public safety officers who come upon the defendant's premises in the discharge of their duties, and since neither Heck nor Johnson involved premises liability, the continued validity of the Rule in Indiana was left unresolved.

16. 32 N.E. 182 (Ill. 1892).

17. Id. at 183-84.

18. Id. at 183 .

19. Id. at 186. 
may enter private property by virtue of a legal authority. ${ }^{20}$ Thus, in exchange for the right to enter one's property, the firefighter is owed a duty of protection only from the landowner's willfully or wantonly injurious conduct. Although this particular standard has since been abandoned in Illinois, the state still uses the Fireman's Rule. ${ }^{21}$

One of the two most widely cited cases applying the Fireman's Rule is Walters $v$. Sloan. ${ }^{22}$ In Walters, a police officer was injured by a minor whom the officer was arresting for public intoxication after the minor left a

20. Id. at 183-84. See, e.g., MD. ANN. CODE art. 48, §181 (1994), which gives firefighters

the authority without liability for trespass at any time of the day or night . . . [t]o enter at their own risk any building, including private dwellings, or upon any premises where a fire is in progress, or where there is reasonable cause to believe a fire is in progress, for the purpose of extinguishing the fire. . . . [And t]o enter at their own risk any building, including private dwellings, or premises near the scene of the fire for the purpose of protecting the building or premises or for the purpose of extinguishing the fire which is in progress in another building or premises[.]

In Illinois, 740 ILL. COMP. STAT. ANN. 75/1 (West 1993) provides that firefighters engaged in their duties "may enter upon the lands of any person, firm, private or municipal corporation or the State of Illinois to carry out his or her duties and while so acting shall not be criminally or civilly liable for entering upon such lands." See also, ALASKA STAT. § 18.70.075 (Michie 1996) (granting firefighters the power to trespass upon the land of another to extinguish a fire on that property or to enter non-involved property for the purposes of protecting the non-involved property or extinguishing a fire on other property), and Meiers v. Fred Koch Brewery, 127 N.E. 491,492 (N.Y. 1920) (explaining that there really is no invitation by the landowner and no acceptance by the firefighter to come upon the landowner's property).

21. See Hedberg v. Mendino, 579 N.E.2d 398 (Ill. App. Ct. 1991). In Hedberg, the court stated that firefighters are owed the same duty of care as invitees. Id. at 399 . Note, however, that " while a landowner owes a duty of reasonable care to maintain his property so as to prevent injury occurring to a fireman from a cause independent of the fire he is not liable for negligence in causing the fire itself.'" Id. (quoting Washington v. Atlantic Richfield Co., 361 N.E.2d 282, 285 (Ill. 1976)).

The following cases, like Hedberg, held that landowners are not liable at common law for negligence in creating a condition that prompts the response of firefighters and that proximately causes injury to the firefighters: Grable v. Varela, 564 P.2d 911 (Ariz. Ct. App. 1977); Washington v. Atlantic Richfield Co., 361 N.E.2d 282 (Ill. 1976); Koehn v. Devereaux, 495 N.E.2d 211 (Ind. Ct. App. 1986); Thompson v. Warehouse Corp. of Am., 337 So.2d 572 (La. Ct. App. 1976); Phillips v. Hallmark Cards, Inc., 722 S.W.2d 86 (Mo. 1986); Pottebaum v. Hinds, 347 N.W.2d 642 (lowa 1984); Berko v. Freda, 412 A.2d 821 (N.J. 1983); Ferraro v. Demetrakis, 400 A.2d 1227 (N.J. Super. Ct. App. Div. 1979), cert. denied, 405 A.2d 834 (N.J. 1979); Hawkins v. Sunmark Indus., Inc., 727 S.W.2d 397 (Ky. 1986); Fletcher v. Illinois C. G. R. Co., 679 S.W.2d 240 (Ky. Ct. App. 1984); England v. Tasker, 529 A.2d 938 (N.H. 1987); Buchanan v. Prickett \& Son, Inc., 279 N.W.2d 855 (Neb. 1979); Held v. Rocky River, 516 N.E.2d 1272 (Ohio Ct. App. 1986); and Moreno v. Marrs, 695 P.2d 1322 (N.M. Ct. App. 1984).

22. 571 P.2d 609 (Cal. 1977). 
party. The officer sued the owners of the home in which the party was held. In denying recovery, the court explained that one reason the officer could not recover was that he, with knowledge of the danger, voluntarily elected to confront it. ${ }^{23}$ A second reason given by the court was that an individual should not be allowed recovery for injuries sustained from the very situation that requires his engagement as an officer. ${ }^{24}$ This argument implies that a civilian should not be held liable for calling upon a public safety officer to do the very job that the public safety officer is employed to do. The third reason advanced by the court is that safety officers are indeed compensated for the risks they confront. ${ }^{25}$ For example, firefighters receive a competitive wage, health insurance, ${ }^{26}$ workers' compensation, ${ }^{27}$ and pension fund benefits. ${ }^{28}$ Thus, the argument that firefighters are inadequately compensated for injuries because after-injury compensation (i.e., workers' compensation) is insufficient does not consider the entire spectrum of financial benefits provided to public safety officers.

The final concern of the Walters court was that abolishing the Fireman's Rule would result in an explosion of litigation. ${ }^{29}$ "Whether the employee is ultimately compensated with money derived from taxes or from insurance, the public pays the bill. ${ }^{n 0}$ Thus, it is more efficient simply to mandate recovery from the pre-established, publicly-funded system since public moneys will pay for the injury in either scenario.

In his famous dissent in Walters, Justice Tobriner attempted to rebut the long-standing principles of the Fireman's Rule. ${ }^{31}$ Justice Tobriner first

23. Id. at 612 .

24. Id.

25. Id. at 612-13.

26. See, e.g., Schedule of Benefits, in Washington Civil TOWNSHIP (INDIANA), EMPLOYEE SUMMARY PLAN DESCRIPTION 12-19 (1992) [hereinafter EMPLOYEE SUMMARY PLAN] (setting forth insurance packages and parameters for drug, dental, and medical benefits). See also Coordination of Benefits, Continuation of Coverage (COBRA), in EMPLOYEE SUMMARY PLAN, supra, at 47-49 (providing for the extension of insurance benefits package after leaving the fire service).

27. See, e.g., MD. ANN. CODE art. 38A, § 39 (1997); MINN. STAT. ANN. § 176.011 (West 1993 \& Supp. 1997) and MINN. STAT. ANN. § 69.52 (West 1996); TEX. [LAB.] CODE ANN. $\$ \$ 504.001$ to 504.073 (West 1996); and WIS. STAT. ANN. $\$ 102.03$ (West 1997).

28. See, e.g., MD. CODE ANN., [STATE PERs. \& PENS.] \& 28-101 to 28-403 (1997); 40 ILl. COMP. STAT. ANN. 5/4-101 to 5/4-144 (West 1993 \& Supp. 1997) and 40 ILL. CoMP. STAT. ANN. 5/6-101 to 5/6-226 (West 1993 \& Supp. 1997); D.C. CODE ANN. § 4-601 to 4634 (1994 \& Supp. 1997); ALASKA STAT. $\$ 39.35 .010$ to 39.35 .690 (Michie 1996); and GA. CODE ANN. § 47-7-1 to 47-7-126 (1993 \& Supp. 1997).

29. Walters, 571 P.2d at 613 .

30. Id.

31. The foundations of Justice Tobriner's arguments are briefly set forth in this Part. Please note, however, that a discussion of the faultiness of Justice Tobriner's theories is undertaken in Part III, infra. 
pointed out that firefighters are unfairly denied recovery because of the inherent dangers of their jobs while other employees with dangerous jobs are allowed recovery in tort. ${ }^{32}$ For example, highway and construction workers may recover for injuries sustained from the negligence of third parties. ${ }^{33}$ According to Justice Tobriner, because firefighters are likewise exposed to the risks of third-party negligence, firefighters should be allowed tort recovery as well. Justice Tobriner also criticized the idea that there is no greater danger in fighting a negligently started fire than there is fighting a non-negligently started fire. ${ }^{34}$ He argued that the "fortuity" of a particular fire being started negligently should not bar recovery. ${ }^{35}$ He further suggested that a negligently started fire involves a higher degree of risk because it is simply an additional fire that must be fought. ${ }^{36}$ Justice Tobriner additionally criticized the rule's cost-spreading rationale. Because other employees covered by workers' compensation are allowed recovery from third-party tortfeasors, firefighters should be entitled to such recovery as well. ${ }^{37}$ He emphasized the increasing role of insurance in compensating for injuries resulting from negligence. ${ }^{38}$ Justice Tobriner's final criticism was that judicial economy should not serve as a basis for denying recovery. $\mathrm{He}$ argued that many of the issues that would be resolved in a firefighter's tort case were already being litigated in cases of fire-related property damage and personal injuries to persons other than firefighters. ${ }^{39}$

The other frequently cited case involving the Fireman's Rule is Krauth v. Geller. ${ }^{40}$ In that case, Justice Weintraub discussed two bases for the Fireman's Rule: firefighters' sui generis status, and assumption of risk (including public policy). As for the firefighters' sui generis status, the court in Krauth noted that firefighters have a legal right to enter the premises regardless of whether they are invited by the landowner. ${ }^{41}$ Because firefighters may not legally be kept from entering a landowner's premises, they do not fit well within traditional land entrant categories (i.e., invitees and licensees) and are appropriately included in a class of their own. In discussing both assumption of risk and public policy, the court noted that "it is the fireman's business to deal with that very hazard and hence . . . he

32. Walters, 571 P.2d at 617 (Tobriner, J., dissenting).

33. Id.

34. Id. at 618 .

35. Id.

36. Id.

37. Id. at 619.

38. Id.

39. Id. at 620 .

40. 157 A.2d 129 (N.J. 1960).

41. Id. at 130 . 
cannot complain of negligence in the creation of the very occasion for his engagement." ${ }^{\text {42 }}$

While recognizing these traditional applications of the Fireman's Rule, the court in Krauth also delineated some exceptions to the Rule. First, recovery by the firefighter will be allowed if he is injured by a hazard created in violation of a safety statute or ordinance passed for the firefighter's protection. ${ }^{43}$ In this scenario, the legislature and, by extension, the people have spoken to allow recovery. A second exception allows firefighters to recover if the occupier has failed to warn of a hidden hazard. ${ }^{44}$ If a landowner could have protected the firefighters with a simple warning, then the landowner should be held liable for resulting injuries. Landowners have also been held liable when they have failed to maintain a reasonably safe entrance to a structure which would otherwise have been open to the public. ${ }^{45}$ Such entrances should always be safe since they are held open to the public, and firefighters should be able to rely upon that assumption when entering public grounds.

The preceding exceptions to the Fireman's Rule are not exhaustive. Firefighters also will be allowed recovery in tort if the nature of the hazard is misrepresented in such a way as to expose the firefighters to an increased

42. Id. at 131 (emphasis added).

43. Id. See also Maloney v. Hearst Hotels Corp., 8 N.E.2d 296 (N.Y. 1937) (storage of dangerous substance), and Drake v. Fenton, $85 \mathrm{~A}$. 14 ( $\mathrm{Pa}$. 1912) (open elevator shaft left unguarded); but $c f$. Flowers v. Rock Creek Terrace, 520 A.2d 361 (Md. 1987) (excluding open elevator shaft and barring recovery by firefighter).

44. Krauth, 157 A.2d at 131. See also Bartels v. Continental Oil Co., 384 S.W.2d 667 (Mo. 1964) (holding landowner liable for firefighter's death where landowner knew of the defective nature of a gas storage tank and failed to wam the firefighter of that danger after the firefighter's arrival); Shypulski v. Waldorf Paper Prod., 45 N.W.2d 549 (Minn. 1951) (holding landowner liable for injuries to firefighter from a wall collapse where the landowner knew that the wall's construction was dangerous, the landowner knew the wall could not withstand lateral pressure, and the landowner had an opportunity to warn the firefighter before the firefighter entered the structure and failed to give such warning), abrogated by MINN. STAT. § 604.06 (1987); Jenkins v. 313-321 W. 37th St. Corp., 31 N.E.2d 503 (N.Y. 1940) (allowing recovery by firefighter from a gas explosion where the landowner or his agents knew that gas was seeping into the closed room wherein the fire was burning and no one warned the firefighters of this hazard), reh'g denied, 33 N.E.2d 547 (N.Y. 1941); Schwab v. Rubel Corp., 37 N.E.2d 234 (N.Y. 1941) (sending issue of defendant's liability to the jury where a firefighter fell into a hole in the floor of an unused building for a determination of whether or not the hole constituted an unusual hazard known by the defendants); and James v. Cities Serv. Oil Co., 31 N.E.2d 872 (Ohio Ct. App. 1939) (allowing recovery by firefighter from gasoline explosion caused by vapors from a recently emptied gasoline tank where the defendant's agents knew of the hazard and failed to warn the injured firefighter of the hazard's presence), aff'd, 43 N.E.2d 276 (Ohio 1942).

45. Krauth, 157 A.2d at 131. See also Meiers v. Fred Koch Brewery, 127 N.E. 491 (N.Y. 1920); Beedenbender v. Midtown Properties, 164 N.Y.S.2d 276 (N.Y. App. Div. 1957); and Taylor v. Palmetto Theater Co., 28 S.E.2d 538 (S.C. 1943). 
risk. $^{46}$ Next, even if the land occupier did not know of the hazard, firefighters will be allowed to recover if they are injured by an unanticipated hazard. ${ }^{47}$ If firefighters are unaware of an item's dangerous condition, they cannot prepare themselves to face the risk. Therefore, it is unfair to bar recovery when the firefighter could have taken appropriate actions to mitigate the chance of injury had he known the hazard existed. Moreover, firefighters will be allowed recovery if injured by a positive wrongful act or reckless or wanton conduct. ${ }^{48}$ The Fireman's Rule is based upon the notion that firefighters may not recover for injuries caused by the hazard prompting their response. On the other hand, a positive wrongful act constituting reckless or wanton conduct is independent of the hazard that prompted the firefighter's response. Accordingly, injuries deriving from a positive wrongful act fall outside the purview of the Fireman's Rule.

At first blush, the Fireman's Rule could be construed to apply to all professional rescuers. The Rule, however, has not been routinely applied to emergency medical technicians (EMTs). The basic reason for not applying the Rule to EMTs is that the nature of the employment of firefighters is wholly different from that of EMTs. ${ }^{49}$ Although ambulance attendants may face danger as an indirect result of their employment, facing danger is not their primary task, and they cannot be held to the same standard as firefighters and police officers whose primary duties involve confronting

46. Lipson v. Superior Court, 644 P.2d 822 (Cal. 1982). The court held the Fireman's Rule inapplicable to the plaintiff-firefighter because the owners of the premises misrepresented the nature of the fire to the firefighters upon their arrival. Id. at 827. The generally accepted basis for the Fireman's Rule is that firefighters may not recover for injuries stemming from causes dependent on the fire. Due to the misrepresentation in Lipson, the firefighters believed they were confronting a wholly different type of fire than they actually found. Thus, since the misrepresentation misled the firefighters and occurred after their arrival on the scene, the court held that it constituted "an act of misconduct independent from any tortious act which may have been the cause of the [fire]." Id. Therefore, independent acts causing injury to firefighters do not fall within the requirements of the Fireman's Rule, and firefighters will be allowed recovery when injured by independent hazards.

47. See, e.g., Haubolt v. Union Carbide Corp., 467 N.W.2d 508 (Wis. 1991). In Haubolt, a defectively manufactured acetylene tank ruptured, exploded, and injured a firefighter. The court held that it would "not expand the firefighter's rule to cover manufacturers whose defective product directly causes injury to firefighters during the course of a fire, when the danger caused by the defective product is not reasonably apparent to them, or a risk anticipated by them." Id. at 512 .

48. See, e.g., Migdal v. Stamp, 564 A.2d 826 (N.H. 1989). In Migdal, a police officer was allowed recovery after being shot on the basis that aiming a gun at and shooting a police officer constitutes "a positive wrongful act." Id. at 829. Additionally, the parents of the minor-shooter were held liable because they knew of their child's mental and emotional instabilities, failed to seek help for their child, and allowed the child access to a firearm and ammunition. Id. at 828. This situation is an exception to the Fireman's Rule since it demonstrates reckless or wanton conduct. Id. at 828-29.

49. See generally Lees v. Lobosco, 625 A.2d 573 (N.J. Super. Ct. App. Div. 1993). 
danger..$^{50}$ Although the purpose of employing firefighters is to have a group readily available to confront fire, which is hazardous by nature, the primary purpose of employing EMTs is to have a group readily available to confront acute injury and acute and chronic illness, which pose no immediate threat to the EMT. Thus, dangers to EMTs arise indirectly, and any resulting injuries should be compensable in tort.

The Fireman's Rule has also been extended to volunteer firefighters. ${ }^{51}$ Volunteer firefighters, like professional firefighters, are trained to be experts in dealing with fires. ${ }^{52}$ Furthermore, the dangers encountered by volunteer firefighters are no different from those encountered by professional firefighters, and volunteer firefighters, like professional firefighters, voluntarily confront these inherent risks. Finally, like professional firefighters, volunteer firefighters have the legal authority to enter private property in order to combat fires. Thus, it is logical to apply the Fireman's Rule to volunteer firefighters as well as to professional firefighters.

In sum, there are several theories for applying the Fireman's Rule. Firefighters may be barred from recovery since they voluntarily face the risks inherent to the calling. Additionally, firefighters already receive compensation-in the form of wages, insurance plans, pension funds, and workers' compensation-for the hazards they face. Preventing an explosion of lawsuits is another reason for barring recovery by firefighters. Firefighters also may be barred recovery under theories that they enter the landowner's premises as licensees or sui generis entrants, which would thereby eliminate any affirmative duty of care on the part of landowners. Thus, even though varying approaches to the Rule have been employed since it was first introduced, it has been a fundamental principle of American tort law for over a century and will likely remain a facet of American jurisprudence for years to come.

50. See, e.g., Krause v. U.S. Truck Co., 787 S.W.2d 708 (Mo. 1990) (holding that the Fireman's Rule was inapplicable to an ambulance attendant). Cf. Kowalski v. Gratopp, 442 N.W.2d 682 (Mich. Ct. App. 1989) (refusing to extend the Fireman's Rule to a paramedic injured from a slip and fall on icy walkway); but cf. Siligato v. Hiles, 563 A.2d 1172 (N.J. Super. Ct. Law Div. 1989) (barring recovery under the Fireman's Rule by a member of a rescue squad forced to witness the death of his own baby). For a discussion of the relationship between the Fireman's Rule and EMTs and paramedics, see Stephen E. Ruscus, Empty Pockets: Application of the Fireman's Rule to Emergency Medical Technicians, $7 \mathrm{~J}$. CONTEMP. Health L. \& Pol'y 339 (1991).

51. See Flowers v. Rock Creek Terrace, 520 A.2d 361 (Md. 1987).

52. For examples of the training requirements for both professional and volunteer firefighters, see IND. CODE ANN. \$ 36-8-10.5-6 (West 1997) (setting forth minimum training requirements for all firefighters) and IND. CODE ANN. § 36-8-10.5-7 (West 1997) (establishing basic training subject matter to be learned by all firefighters). 


\section{THE BASES FOR THE FIREMAN'S RULE IN THE UNITED STATES}

Up to this point, the theories set forth in support of the Fireman's Rule have been primarily descriptive and relatively neutral. This note now undertakes a critical analysis of the bases for the Fireman's Rule. This careful scrutiny of the principles underlying the Rule provides a foundation for the argument that the Rule should be applied in Great Britain. Thus, this part more closely examines the principles of sui generis, assumption of risk, and economic efficiency.

\section{A. Sui Generis Status of Firefighters}

Although the purpose of this section is to discuss firefighters' status as sui generis entrants of land, it is useful to first explore the rationale behind their classification as invitees or licensees. ${ }^{33}$ An examination of these different classifications reveals the superiority of the sui generis classification.

\section{Firefighters as Invitees}

Some American jurisdictions hold that firefighters enter land as invitees. ${ }^{54}$ An invitee is defined as a "person who goes on to [sic] the land of another at the express or implied invitation of the owner or occupant either to transact business or for the mutual benefit of the invitee and the owner or occupant." Lass Landowners owe invitees a "duty of reasonable care." The reasoning behind the classification of firefighters as invitees is that firefighters confer an economic benefit upon the landowner by preventing his property or life from being destroyed. Accordingly, landowners should be held to a higher standard of care because a benefit is conferred upon them.

Although the higher standard of care owed to an invitee might seem to significantly increase a firefighter's chance of recovery, the firefighter is not

53. For a brief explanation of these varying approaches, see David L. Strauss, Where There's Smoke, There's the Firefighter's Rule: Containing the Conflagration After One Hundred Years, 1992 WIS. L. REV. 2031, 2034-35 (1992).

54. The following cases held that firefighters entered land as invitees: Netherton v. Arends, 225 N.E.2d 143 (Ill. App. Ct. 1967); Horcher v. Guerin, 236 N.E.2d 576 (Ill. App. Ct. 1968); Briones v. Mobil Oil Corp., 501 N.E.2d 821 (Ill. App. Ct. 1986); Walsh v. Madison Park Properties, Ltd., 245 A.2d 512 (N.J. Super. Ct. App. Div. 1968); Mistelske v. Kravko, Inc., 88 Pa. D. \& C. 49 (1953); Buckeye Cotton Oil Co. v. Campagna, 242 S.W. 646 (Tenn. 1922); and Strong v. Seattle Stevedore Co., 466 P.2d 545 (Wash. Ct. App. 1970).

55. Clem v. United States, 601 F. Supp. $835,841-42$ (N.D. Ind. 1985).

56. Strong, 466 P.2d at 548. 
assured recovery. ${ }^{57}$ Despite their invitee status, firefighters have been denied recovery because of their superior knowledge about fire and its behavior. ${ }^{38}$ Another situation in which recovery has been denied involves the fire inspector who is injured by that which he was called upon to inspect. 59 Reasonable care under these circumstances does not require a landowner to "affirmatively guard against defects in the apparatus" that the inspector has entered the premises specifically to investigate. ${ }^{60}$ That the injured inspector was summoned to inspect potential violations of safety codes alerts him to be on guard for dangerous conditions; indeed, if there were no risk, he would not have been summoned in the first place. ${ }^{61}$

It is not difficult to see how these principles extend to firefighters injured in the line of duty. The need for firefighters is premised upon the likelihood that dangerous conditions exist. If dangerous conditions are expected, then the firefighter is on notice of their potential existence, and the land occupier should be relieved of liability if the firefighter is injured by one of the expected risks, such as structural collapse or dangerous internal structural conditions.

Although firefighters sometimes have been treated as invitees, there is no real change in the landowner's liability under such a classification. Furthermore, firefighters do not fit well into this category. There is no way for the invitee classification to address the unique nature of firefighting and the particular risks involved in that calling. Accordingly, many jurisdictions have regarded firefighters as licensees.

57. See Horn v. Urban Inv. \& Dev. Co., 519 N.E.2d 489 (Ill. App. Ct. 1988).

I] $f$ the fireman is on the premises in the performance of his official duties at a place where he might reasonably be expected to be, he is owed the same duty which the possessor of land owes to an invitee, that is, to protect him against dangerous conditions constituting an unreasonable risk of harm which the landowner/occupier should expect the invitee will not discover or realize or will fail to protect himself against; but there is no duty to warn against risks which are known or obvious.

Id. at 492 . See, e.g., Horcher v. Guerin, 236 N.E.2d 576 (Ill. App. Ct. 1968) (denying recovery because the landowner adequately warned the firefighter of the danger when he called the fire department for help); Netherton v. Arends, 225 N.E.2d 143 (Ill. App. Ct. 1967) (denying recovery to firefighter for smoke-inhalation injuries that were incidental to his employment); and Mistelske v. Kravko, Inc., 88 Pa. D. \& C. 49 (1953) (approving instructions to the jury that a fireman was an implied invitee, but that he assumed the risk of the fire's loosening a cable attached to a counterbalance).

58. Strong, $466 \mathrm{P} .2 \mathrm{~d}$ at 550.

59. See Walsh v. Madison Park Properties, Ltd., 245 A.2d 512 (N.J. Super. Ct. App. Div. 1968).

60. Id. at 516 .

61. Id. 


\section{Firefighters as Licensees}

A more traditional classification of firefighters is that they enter land as licensees; ${ }^{62}$ this was the classification employed in the first case that applied the Fireman's Rule. ${ }^{63}$ A licensee may be defined as "one who enters the premises of another for his own convenience, curiosity or excitement." The notion behind this approach is that firefighters do not confer an economic benefit upon the landowner. Instead, a firefighter acts to prevent an economic loss. Benefit conferral and loss prevention are two different concepts. The former attempts to place the individual in a better position, whereas the latter seeks only to preserve the status quo. Economic benefit cannot logically form the foundation for a duty of care owed to firefighters.

Next, the firefighter's invitation to the premises must be considered. Whether or not the firefighter is actually invited onto the landowner's property by the landowner is irrelevant because the firefighter is given the right by law to enter the landowner's premises. ${ }^{65}$ Since the landowner does not decide whether the firefighter may come onto his property, it is unfair to hold the landowner to a standard of care any higher than that owed to a licensee.

Finally, the landowner has no means by which to predict when a firefighter's services will be needed. ${ }^{66}$ If the landowner cannot predict when

62. The following cases held that firefighters enter land as licensees: Gibson v. Leonard, 32 N.E. 182 (III. 1892); Roberts v. Rosenblatt, 148 A.2d 142 (Conn. 1959); Todd v. Armour \& Co., 162 S.E. 394 (Ga. Ct. App. 1931); Baxley v. Williams Constr. Co., 106 S.E.2d 799 (Ga. Ct. App. 1958); Wilbanks v. Echols, 433 S.E.2d 134 (Ga. Ct. App. 1993); Pincock v. McCoy, 281 P. 371 (Idaho 1929); Steinwedel v. Hilbert, 131 A. 44 (Md. 1925); Aravanis v. Eisenberg, 206 A.2d 148 (Md. 1965); Brosnan v. Koufman, 2 N.E.2d 441 (Mass. 1936); Aldworth v. F. W. Woolworth Co., 3 N.E.2d 1008 (Mass. 1936); New Omaha Thomson-Houston Electric Light Co. v. Anderson, 102 N.W. 89 (Neb. 1905); New Omaha Thomson-Houston Electric Light Co. v. Bendson, 102 N.W. 96 (Neb. 1905); Wax v. Cooperative Refinery Ass'n, 49 N.W.2d 707 (Neb. 1951); Moravec v. Moravec, 343 N.W.2d 762 (Neb. 1984).

63. See generally Gibson v. Leonard, 32 N.E. 182 (Ill. 1892).

64. Clem v. United States, 601 F. Supp. 835, 842 (N.D. Ind. 1985).

65. See supra text accompanying note 20.

66. See William L. Prosser, Business Visitors and Invitees, 26 MinN. L. REV. 573 (1942). Prosser states:

Why ... are visiting firemen and policemen set apart as a class to whom no duty is owed to inspect and prepare the premises? One obvious reason . . . is that these individuals enter at unforeseeable moments, upon unusual parts of the premises, and under circumstances of emergency, where care in preparation cannot reasonably be looked for. A man who climbs in through a basement window in search of a fire or a thief cannot expect an assurance that he will not find a bulldog in the cellar. Regardless of benefit or invitation, there is no reason to suppose that the place has been made safe.

Id. at 610 . 
firefighters will come to his premises, it is impossible for the landowner to prepare the premises for their arrival. To require an owner or occupier to exercise at all times the high degree of care owed to an invitee "would be an intolerable burden which it is not in the best interest of society to impose. ${ }^{n 67}$ Thus, the most logical approach is to require the firefighter, like the landowner, to take the premises as he finds them; this is the approach embodied in the licensee classification.

As licensees, firefighters are subject to the standard that "the licensor assumes no duty to the licensee, except the duty to refrain from affirmative or willful acts that work an injury."68 The basic rationale behind this standard is that it is unfair to allow a landowner to take affirmative steps to injure an innocent visitor to his property. Firefighters can reasonably be expected to take the premises as they find them because the landowner is not expected to take steps to prepare the premises for the arrival of firefighters in an emergency. But when the landowner acts willfully or wantonly, the landowner's action shifts from sitting idly on the property to actively taking steps toward injuring the firefighter. It is fair to allow recovery by firefighters when the landowner commits such acts because the premises are no longer as the firefighter originally found them; rather they change with each new affirmative or willful act of the landowner.

Given the unpredictable nature of fires and the unpredictable modes of ingress and egress used by firefighters, basing liability upon the idea of firefighters as licensees seems practical and just. It is certainly a widely supported position and works better than trying to classify firefighters as invitees. However, the reasons for classifying firefighters in this way do not form the traditional basis for a licensee classification. The traditional basis is that a licensee is a guest invited upon the property by the landowner. Classifying firefighters as licensees ignores this traditional rationale since firefighters have a legal right to enter the property without an invitation or

67. Baxley, 106 S.E.2d at 805 .

68. Gibson, 32 N.E. at 184. See also Whittin v. Miami-Dade Water \& Sewer Auth., 357 So. 2d 430 (Fla. Dist. Ct. App. 1978) (holding that injuries resulting from toxic fumes not attributable to defendant-landowner since the injuries from the fumes were not caused by wanton or willful conduct), cert. denied, 364 So. $2 d 894$ (Fla. 1978), abrogated by Fla. STAT. ch. 112.182 (1990); Todd v. Armour \& Co., 162 S.E. 394, 395 (Ga. Ct. App. 1931) (denying recovery to firefighter injured by fall into open stairwell because maintenance of an open stairwell did not constitute willful and wanton negligence); Flowers v. Sting Sec., Inc., 488 A.2d 523 (Md. Ct. Spec. App. 1985) (denying plaintiff-firefighter recovery from a fall into an open elevator shaft since the landowner did not act wantonly or willfully); Lave v. Neumann, 317 N.W.2d 779, 781 (Neb. 1982) (holding that an occupant's duty only requires refraining from willful or wanton negligence or designed injury, " "except in certain cases where there may be a duty to warn of hidden danger or peril known to the owner but unknown to, or unobservable by, firefighters in the exercise of ordinary care'" (quoting Wax v. CoOperative Refinery Ass'n., 49 N.W.2d 707, 709 (Neb. 1951)). 
permission. The proper approach to classifying firefighters, therefore, treats them as sui generis entrants on the land.

\section{Firefighters as Sui Generis Entrants}

The theory that the firefighters are invitees or licensees simply places firefighters into categories in which they do not belong. ${ }^{69}$ There are two reasons that these classifications do not work. First, the designation of invitee or licensee implies that the individual was invited onto the property. That is not necessarily the case with firefighters. Firefighters, in discharging their duties, will come onto the owner's property whether the owner likes it or not. Firefighters are given the right to enter one's property by law and cannot be kept from entering the property. ${ }^{70}$ Second, while a landowner can force an invitee or licensee to leave his premises, ${ }^{71}$ he cannot force firefighters to leave. Indeed, firefighters can require the landowner to leave his own property, and should the landowner attempt to remove the firefighters, the landowner may face criminal liability for interfering with fire scene operations. ${ }^{2}$ Usually, if a landowner believes that the conditions

69. Meiers v. Fred Koch Brewery, 127 N.E. 491,492 (N.Y. 1920) (concluding that a landowner does not extend an invitation to the firefighter since the firefighter has a duty to enter the premises regardless and that "[u]nder such circumstances it is a misuse of terms to call him a bare licensee."). The following cases also recognize the sui generis classification: Buren v. Midwest Indus., Inc., 380 S.W.2d 96 (Ky. Ct. App. 1964); Krauth v. Geller, 157 A.2d 129 (N.J. 1960); Jackson v. Velveray Corp., 198 A.2d 115 (N.J. Super. Ct. App. Div. 1964); Berko v. Freda, 459 A.2d 663 (N.J. 1983); Beedenbender v. Midtown Properties, Inc., 164 N.Y.S.2d 276 (N.Y. App. Div. 1957); McGee v. Adams Paper \& Twine Co., 271 N.Y.S.2d 698 (N.Y. App. Div. 1966), aff'd, 233 N.E.2d 289 (N.Y. 1967); McCarthy v. Port of New York Auth., 290 N.Y.S.2d 255 (N.Y. App. Div. 1968); Carpenter v. O'Day, 562 A.2d 595 (Del. Super. Ct. 1988), aff'd without opinion, 553 A.2d 638 (Del. 1988); and Pearson v. Canada Contracting Co., 349 S.E.2d 106 (Va. 1986).

70. See supra text accompanying note 20 .

71. See WILLIAM L. PROSSER, LAW OF TORTS $\$ 61$, at 395 (4th ed. 1971) (discussing the possessor's "power of control or expulsion which his occupation of the premises gives him over the conduct of a third person who may be present, to prevent injury to the visitor at his own hands").

72. See, e.g., MICH. CoMp. LAws ANN. $\$ 750.241$ (West 1997), which states:

(1) Any person who shall knowingly and willfully hinder, obstruct, endanger or interfere with any fireman in the performance of his duties is guilty of a felony.

(2) Any person who, while in the vicinity of any fire, willfully disobeys any reasonable order or rule of the officer commanding any fire department at such fire, when such order or rule is given by the commanding officer or a fireman there present, is guilty of a misdemeanor.

See also IND. CODE ANN. $\S 35-44-3-8$ (West 1986) (“[a] person who knowingly or intentionally obstructs or interferes with a fireman performing or attempting to perform his emergency functions or duties as a fireman commits obstructing a fireman, a Class A misdemeanor") (Under IND. CODE ANN. § 35-50-3-2 (West 1986), a Class A misdemeanor 
of his premises are unsafe for invitees or licensees, the landowner can make them leave and thereby avoid the threat of liability for negligence. ${ }^{73}$ For example, assume $A$ invites $B$ to A's home for a social gathering. During the course of the gathering, a window is shattered, thereby exposing $B$ to the risk of injury. A can tell $B$ to leave until the situation is made safe. By law, $B$ has to comply with A's command, and A is allowed to relieve himself of all potential liability. The landowner loses this right with regard to firefighters. For example, if a fire were to break out in a landowner's garage, the landowner could attempt to prevent injury to any firefighters arriving on the scene by requesting that they simply allow the property to burn. Such a request, however, would likely be ignored. Without the Fireman's Rule, the landowner would then be subject to liability even though he had taken maximum steps to remedy the firefighters' exposure to danger. Because the law effectively requires the landowner to watch idly as firefighters place themselves in peril, the Fireman's Rule serves to mitigate the landowner's liability from this powerlessness. ${ }^{74}$

Furthermore, invitees and licensees come onto an owner's premises at foreseeable times. Normally, an invitee will come onto the premises for routine business purposes, and a licensee will come onto the premises for a planned gathering. Firefighters, on the other hand, enter property under circumstances of emergency. Landowners are therefore unable to predict when firefighters will be called. In circumstances requiring the fire department's response, a landowner simply will not have time to prepare the

is punishable by not more than one year in jail and not more than a $\$ 5000$ fine); MD. ANN. CODE art. 27, § 11D (1996) (making it a misdemeanor, punishable by not more than three years in prison, to "interfere with or obstruct . . . a fire fighter, rescue squad member, or emergency services personnel, while the . . . fire fighter, rescue squad member, or emergency services personnel is fighting a fire, performing emergency service, proceeding to a fire or other emergency, or while dispatched to a call for emergency service" ${ }^{\prime}$; and KY. REV. STAT. ANN. \$ 519.020 (Michie 1990) (“[a] person is guilty of obstructing governmental operations when he intentionally obstructs, impairs or hinders the performance of a governmental function by using or threatening to use violence, force or physical interference").

73. See supra text accompanying note 71 .

74. Discussing this approach is Buren v. Midwest Industries, Inc., 380 S.W.2d 96 (Ky. Ct. App. 1964). In that case the court explains:

When [the firefighter] arrives on the scene the field is his. The owner has no power to direct or control his actions. He may not order him to stay outside, or to stay off the roof, or to wear a . . mask, or to limit his actions to shooting water into the building from a safe position outside. To hold the owner responsible while denying him any right or discretion to say what the firemen shall or shall not do would not consist with what this court believes to be the fundamental law of liability by reason of negligence. Having bound his hands, the law cannot justly inflict upon him the consequences of what he might otherwise have been able to prevent.

Id. at 99 . 
premises for the firefighters' arrival. The sui generis status accounts for the fact that a landowner will likely be unable to predict when firefighters will be needed, and it accordingly lowers the standard of care owed to firefighters as compared to that owed to invitees or licensees. ${ }^{75}$ Considering the unpredictable nature of firefighters' responses, firefighters are most appropriately placed within the sui generis category.

The duty owed to firefighters as sui generis entrants accounts for the limited control the landowner has over a firefighter as compared to a business patron or a social guest. The landowner's essential duty to individuals in this classification is to warn them of hidden or unanticipated dangers, but the landowner has no duty to discover hidden defects on the premises. ${ }^{76}$ Under the circumstances of a typical fire, ${ }^{4 i t}$ is not reasonable to require the level of care that is owed to invitees or, without some modification, the level of care owed to licensees."

\section{B. Assumption of Risk}

Assumption of risk takes one of the following two forms: primary or secondary. When risk is assumed by the plaintiff in the primary sense, the defendant owes no duty to the plaintiff in the first place. ${ }^{78}$ Secondary assumption of risk, on the other hand, takes into account the plaintiff's contributory negligence and apportions fault accordingly. ${ }^{79}$ Assumption of

75. See, e.g., Pearson v. Canada Contracting Co., Inc., 349 S.E.2d 106 (Va. 1986).

[F]iremen and policemen, unlike invitees or licensees, enter at unforeseeable times and go upon unusual parts of the premises, including areas not open to the public. Except for scheduled inspections, their presence at any particular time cannot be reasonably anticipated. In such situations, it is not reasonable to require the level of care that is owed to invitees or, without some modification, the level of care owed to licensees.

Id. at 111 .

76. Beedenbender v. Midtown Properties, Inc., 164 N.Y.S.2d 276, 281 (N.Y. App. Div. 1957).

The owner owes no duty to those privileged to enter irrespective of consent to safeguard those parts of his property not ordinarily utilized for passage through the premises, or to discover potential dangers therein, for the entry thereon by such persons under unusual conditions at any hour of the day or night is not reasonably foreseeable.

Id. For other cases employing the duty to warn of hidden dangers standard, see infra note 90 .

77. Pearson, 349 S.E.2d at 111.

78. Meistrich v. Casino Attractions, Inc., 155 A.2d 90, 93 (N.J. 1959).

79. Id. In summing up its conclusions of law, the Meistrich court stated: each case must be analyzed to determine whether the pivotal question goes to defendant's negligence or to plaintiff's contributory negligence. If the former, then what has been called assumption of risk is only a denial of breach of duty and the burden of proof is plaintiff's. If on the other hand assumption of risk is advanced to defeat a recovery despite a demonstrated breach of defendant's 
risk occurs "where the plaintiff voluntarily enters into some relation with the defendant, with knowledge that the defendant will not protect him against the risk. He may then be regarded as tacitly or impliedly consenting to the negligence, and agreeing to take his own chances. ${ }^{80}$ One court has noted that "the fireman's rule is based on a principle as fundamental to our law today as it was centuries ago .... [ [O]ne who has knowingly and voluntarily confronted a hazard cannot recover for injuries sustained thereby. ${ }^{\text {"81 }}$

No one can doubt that firefighting is inherently dangerous. The fact that firefighters must wear self-contained breathing apparatus and numerous layers of protective clothing when fighting a fire is evidence of fire's hazardous nature. Additionally, intuition suggests that entering a burning structure may lead to serious injury. Firefighters undoubtedly understand and realize the dangerous nature of their work-yet they still choose to confront that danger. Thus, the unavoidable conclusion is that firefighters assume the risks naturally associated with fighting fire. ${ }^{82}$

duty, then it constitutes the affirmative defense of contributory negligence and

the burden of proof is upon defendant.

Id. at $\mathbf{9 7}$. This subsection analyzes only primary assumption of risk as it is the applicable doctrine for the Fireman's Rule because the Rule is based upon the idea that the landowner owes no duty to the firefighter in the first instance. Therefore, if secondary assumption of risk applied, courts would be forced to determine whether or not the landowner breached a duty owed to the firefighter, which runs counter to the assumption-of-risk basis of the Rule. See also Strauss, supra note 53, at 2035-37.

80. Prosser, supra note 71 , at 440 . Prosser then states:

Thus, he may accept employment, knowing that he is expected to work with a dangerous horse; or ride in a car with knowledge that the brakes are defective and the driver incompetent; or he may enter a baseball park, sit in an unscreened seat, and so consent that the players may proceed with the game without taking any precautions to protect him from being hit by the ball. . . . [T] he legal result is that the defendant is simply relieved of the duty which would otherwise exist.

Id. While firefighting is not explicitly set out by the author, it may be included in the list. For instance, a firefighter accepts employment knowing that he is expected to work with dangerous elements, namely fire and those hazards naturally occurring therefrom, thereby relieving the owner of the owner's duty of care.

81. Walters v. Sloan, 571 P.2d 609, 612 (Cal. 1977). "The rule finds its clearest application in situations ... [where] a person who, fully aware of the hazard created by the defendant's negligence, voluntarily confronts the risk for compensation." Id. See also Hubbard v. Boelt, 620 P.2d 156 (Cal. 1980) (following the approach set forth in Walters).

82. “[T] here are certain risks which anyone of adult age must be taken to appreciate: the danger of slipping on ice, of falling through unguarded openings, of lifting heavy objects, of being squeezed in a narrow space, . . . and doubtless many others." PROSSER, supra note 71 , at 448 . Firefighting can certainly be included under the broad "many others" possibility. It can scarcely be argued that anyone of adult age, indeed many of minor age, would not appreciate the risks of working in direct contact with fire. Again, considering the elementary nature of the relationship between danger and fire, the inescapable conclusion is that firefighters assume the risks naturally associated with their calling. See also Flowers v. Rock 
It also should be noted that just because firefighters may not be able to tell precisely which dangers lurk within a burning structure does not mean that they have refused to assume those risks. ${ }^{83}$ Assumption of risk is based less upon precise knowledge of the risk and more upon the consent to confront the dangers that naturally may result under the circumstances. ${ }^{84}$ Thus, although firefighters may not specifically know that a wall is ready to collapse, such a risk is always a possibility in firefighting, and the intent of the firefighters to assume that risk is clearly manifested by their donning protective clothing and entering the structure anyway.

If there is assumption of risk on the part of the firefighter, the landowner owes no duty to him or her. The proper application of assumption of risk considers the duty of the defendant in the first instance. ${ }^{85}$ If there was no duty owed in the first place, assumption of risk cannot be treated as an affirmative defense because affirmative defenses contemplate a duty of care. The impact of this approach is significant. If assumption of risk included an analysis of contributory fault, as in an affirmative defense, the courts would have to consider the reasonableness of firefighters' conduct in confronting the risks in any given situation. Under the primaryassumption-of-risk rationale, the reasonableness of the firefighters' actions is irrelevant because they are owed no duty of care. If firefighters realize and appreciate the danger but willingly opt to confront it, they do so at their own peril.

Creek Terrace, 520 A.2d 361 (Md. 1987) (falling into open elevator shaft is a risk inherent to firefighting), and Castellano v. City of New York, 624 N.Y.S.2d 38 (N.Y. App. Div. 1995) (climbing a ladder without another firefighter to secure it was a risk that the plaintifffirefighter assumed as part of his duties).

83. "[T]he 'determinative factor' in applying the firefighter rule's bar is 'whether the injury sustained is related to the particular danger which police officers [and firefighters] are expected to assume as part of their duties." Zanghi v. Niagra Frontier Transp. Comm'n, 649 N.E.2d 1167, 1172 (N.Y. 1995) (quoting Cooper v. City of New York, 619 N.E.2d 369, 371 (N.Y. 1993)).

84. See PROSSER, supra note 71, at 449. "Since the basis of assumption of risk is not so much knowledge of the risk as consent to assume it, it is quite possible for the plaintiff to assume risks of whose specific existence he is not aware, provided his intent to do so is made clear." Id. (emphasis added).

85. See Krauth v. Geller, 157 A.2d 129, 130-31 (N.J. 1960):

the prevailing rule is sometimes stated in terms of 'assumption of risk,' used doubtless in the so-called 'primary' sense of the term and meaning that the defendant did not breach a duty owed, rather than that the fireman was guilty of contributory fault in responding to his public duty.

See also Kreski v. Modern Wholesale Elec. Supply Co., 415 N.W.2d 178, 185 (Mich. 1987):

Primary assumption of risk is not technically an affirmative defense, as it involves a situation where the defendant does not owe a duty of care to the [firefighter] .... In other words, primary assumption of risk involves a circumstance where the plaintiff agrees in advance to relieve the defendant of a duty of care owed the plaintiff. 
However, simply because firefighters undertake hazardous employment certainly does not mean that they assume all risks that could possibly materialize. Instead, there are some risks that are anticipated and some that are unanticipated. Only anticipated risks are held to be assumed by firefighters. ${ }^{86}$ Thus, assumption of risk is not strictly applied in all situations. In fact, under the assumption-of-risk approach, the landowner owes firefighters a duty of reasonable care to warn them of unanticipated or hidden dangers. ${ }^{87}$ "Thus, the fire fighter may not recover damages from a landowner if his injury is caused by an apparent risk, but may recover if his injury is caused by an unanticipated risk attributable to the landowner's negligence and such negligence is the proximate cause of the injury. ${ }^{n 8}$

For example, firefighters engaged in fighting a garage fire generally do not anticipate dynamite being stored within the structure. If there is dynamite and it explodes, and the firefighters were not warned of its presence, the landowner most likely will be held liable since the danger of stored dynamite is both unanticipated and hidden. Furthermore, because firefighters are owed reasonable care under the circumstances, "a landowner may be held liable to an injured fireman for negligence in allowing the existence of a hidden danger even though the landowner did not know of the danger or have an opportunity to give warning of its existence. ${ }^{89}$ This rationale does not run counter to the notion that firefighters may be barred

86. " $[F]$ iremen ... do not, by accepting dangerous employment, generally assume all risk that may occur. Rather, each situation encountered may involve some risks which are anticipated and assumed and some which are unanticipated and therefore unassumed." Griffiths v. Lovelette Transfer Co., 313 N.W.2d 602, 605 (Minn. 1981) (emphasis added), abrogated by MINN. STAT. § 604.06 (1984).

87. "[U]nder the assumption of risk rationale, fire fighters do not assume the risk of injury from hidden and unanticipated dangers, so landowners continue to owe fire fighters a duty of reasonable care with respect to such risks." Daniel F. Sullivan \& Jonathan M. Purver, Breach of Duty of Care to Fire Fighter or Police Officer, 41 AM. JUR. P.O.F.2d § 6, at 151 (1985 \& Supp. 1997).

88. Hedberg v. Mendino, 579 N.E.2d 398, 400 (Ill. App. Ct. 1991).

89. Sullivan \& Purver, supra note $87, \S 6$, at 151 . The following cases recognize that landowners may be held liable for failure to warn of hidden dangers: Netherton v. Arends, 225 N.E.2d 143 (Ill. App. Ct. 1967); Bartels v. Continental Oil Co., 384 S.W.2d 667 (Mo. 1964); Aravanis v. Eisenberg, 206 A.2d 148 (Md. 1965); Moravec v. Moravec, 343 N.W.2d 762 (N.M. 1984); Moreno v. Marrs, 695 P.2d 1322 (N.M. Ct. App. 1984); Jenkins v. 313321 W. 37th St. Corp., 31 N.E.2d 503 (N.Y. 1940), reh'g denied, 33 N.E.2d 547 (N.Y. 1941); Schwab v. Rubel Corp., 37 N.E.2d 234 (N.Y. 1941); Beedenbender v. Midtown Properties, Inc., 164 N.Y.S.2d 276 (N.Y. App. Div. 1957); McGee v. Adams Paper \& Twine Co., 271 N.Y.S.2d 698 (N.Y. App. Div. 1966), aff'd, 233 N.E.2d 289 (N.Y. 1967); McCarthy v. Port of New York Auth., 290 N.Y.S.2d 255 (N.Y. App. Div. 1968); Mason Tire \& Rubber Co. v. Lansinger, 140 N.E. 770 (Ohio 1923); James v. Cities Serv. Oil Co., 43 N.E.2d 276 (Ohio 1942); Youngstown v. Cities Serv. Oil Co., 31 N.E.2d 876 (Ohio Ct. App. 1940); Rogers v. Cato Oil \& Grease Co., 396 P.2d 1000 (Okla. 1964); Mignone v. Fieldcrest Mills, 556 A.2d 35 (R.I. 1989); and Clark v. Corby, 249 N.W.2d 567 (Wis. 1977). 
recovery for risks inherent to firefighting. In the preceding scenario, unlike in a situation involving an inherent risk, the firefighters did not anticipate stored dynamite and could not be held to assume a risk for which they did not have a chance to prepare. Naturally, if a danger is hidden and unanticipated, it will not be a danger inherent to firefighting. Since firefighters cannot be held to be aware of hidden and unanticipated risks, they should not be barred from recovery when injured by such risks. ${ }^{90}$

Despite its apparent logic, the assumption-of-risk doctrine has been thoroughly criticized as the basis for the Fireman's Rule. There are five major arguments levied against the assumption-of-risk-rationale.

The first argument claims that since workers in other inherently dangerous occupations, such as road repair, may recover for injuries in tort, firefighters should be able to as well. ${ }^{91}$ However, the primary task of the roadworker is not to encounter danger. The primary job of a roadworker is to fix the road, not to face on-coming traffic. Similarly, it is not the letter carrier's primary task to confront the territorial dog, nor is it the convenience store manager's primary job to encounter the crazed gunman. These dangers are secondary to these types of employment. Firefighters, on the other hand, are primarily employed to face the hazards associated with fire. Allowing a firefighter to recover in tort for injuries stemming from the

90. Bartels v. Continental Oil Co., 384 S.W.2d 667 (Mo. 1964), provides a most enlightening discussion of this principle. In that case, several firefighters were killed when an inadequately vented oil storage tank exploded. The defendant was aware that the tank was improperly vented and that such ventilation increased the risk of explosion. The defendant, however, never disclosed this information to the firefighters. On explosion, the tank which caused the firefighters' deaths "left its concrete cradle and 'rocketed' or was catapulted 75 to 100 feet over the filling station into Southwest Boulevard and 'a ball of fire' engulfed several crews of fire fighters . . . killing one bystander and five firemen." Id. at 669 . "[A]dmittedly, an experienced fire captain would of course accept the presence of kerosene and gasoline as a known hazard of a fire in a gasoline storage facility. But the law does not compel firemen in fighting a fire to assume all possible lurking hazards and risks." Id. (citations omitted). In holding the defendant liable, the court stated that "in these particular . . . circumstances the evidence favorable to the plaintiffs supports the finding of a known hidden danger of which there was no warning whatever, a hazard that in any and all events Bartels as a fireman was not bound to accept as a usual peril of his profession." Id. at 671.

See also Lipson v. Superior Court, 644 P.2d 822 (Cal. 1982). In allowing recovery by the firefighter, the Lipson court held that the conduct in question occurred after the fireman arrived and that the conduct resulted in a heightened exposure to risk. Id. at 827. The court further stated:

the risk that the owner or occupier of a burning building will deceive a firefighter as to the nature or existence of a hazard on the premises is not an inherent part of a firefighter's job. A fireman cannot reasonably be expected Id. at 828 .

to anticipate such misconduct on the part of an owner or occupier of a building.

91. Walters v. Sloan, 571 P.2d 609, 617 (Tobriner, J., dissenting). 
inherent risks of his job would be like allowing a boxer to recover from his opponent for battery-it makes no sense.

The second approach challenges the notion that firefighters voluntarily confront the hazards associated with firefighting. ${ }^{92}$ Because firefighters are always required to confront the hazards of fire, they cannot be held to encounter these hazards voluntarily ${ }^{93}$ This argument, however, has no basis in fact. In reality, firefighters are allowed some latitude when deciding whether or not to confront a particular hazard. ${ }^{94}$ Sometimes a situation is so dangerous that firefighters simply allow the structure to burn and focus on keeping surrounding exposures cooled down. It therefore runs contrary to standard firefighting principles to argue that firefighters are required to dash into a raging inferno regardless of the circumstances. Firefighters are highly-trained specialists whose professional judgment may dictate that they not face a particular hazard.

As for those risks that require confrontation by firefighters, it is not unjust or impractical to conclude that firefighters implicitly assume those risks when they become firefighters. Presumably, firefighters voluntarily decide to join the profession. It is difficult to imagine that an individual

92. See Note, Assumption of the Risk and the Fireman's Rule, 7 WM. MrTCHELL L. REV. 749, 769 (1981) [hereinafter Fireman's Rule].

93. Id. "The voluntariness of a fireman's . . . conduct is questionable in light of the nature of [his/her] employment . . . . While it is true that they initially accept employment voluntarily, firemen . . . are not allowed to pick and choose among the dangers they are willing to face." Id.

94. "Once a conscious decision has been made to fight a fire it is important to remain calm and keep a clear perspective regarding safety." WASHINGTON TOWNSHIP FIRE DEPARTMENT (INDIANA), BASIC FIREFIGHTER TRAINING MANUAL 30 (1995). If a conscious decision to fight the fire may be made, then by necessity a conscious decision not to fight the fire may be made, too. "If fire conditions are so advanced or the condition of the building so poor that rescuers have a good chance of losing their lives, rescue should not be attempted

... [because] it is unlikely the victim would be alive." Id. at 273.

There are times when interior attack is not advisable because of the peril of structural collapse or because hand-held nozzles cannot provide the required water flow. In such cases, the next tactic is to fall back upon artillery rather than infantry, and resort to the use of master streams.

William E. Clark, Firefighting Principles \& Practices 277 (2d ed. 1991). When the preceding quote refers to master streams, it means that the firefighters surround the structure from a distance and spray large volumes of water into the structure, as opposed to actually entering the structure. This tactic is referred to as the "surround and drown" method in firefighting circles.

"Limited access to ceiling spaces and the danger of ceiling collapse usually rule out interior firefighting at well-advanced church fires." Id. at 401 (fig. 16.27). "Rural firefighting is often devoted almost entirely to the protection of exposures." Id. at 423.

"The risk concept found in this hazardous occupation recognizes acceptance of certain dangers as almost inevitable, yet it does not require extreme personal risk unless there is no alternative." Id. at 95-96. A situation of "no alternative" would be when a known, living civilian or firefighter is trapped in the structure. 
would not be aware of the basic risks associated with fighting fires at the time he or she decides to join the fire department.

The next argument is that the Fireman's Rule acts as a disincentive to the safe maintenance of property and to fire prevention. ${ }^{95}$ Under this argument, because negligent landowners will not be held liable for injuries to firefighters, they will not take care to prevent fires. However, this argument assumes too much. It implies that people are indifferent about burning down their houses and businesses. Yet it is just not logical to conclude that, because of the Fireman's Rule, people will decide to stop guarding against fires. The threat of being left homeless and possessionless is enough of an incentive to make people guard against fires. Given the magnitude of that threat, people undoubtedly take as much care now as they would if they were to be held liable in tort to firefighters. The Fireman's Rule has been in effect for over a century, and people have always taken care not to burn down their dwellings and businesses. The last 105 years have not seen widespread carelessness on the part of landowners, and such carelessness is not likely to develop in the future, as long as people continue to value their property and possessions.

The fourth argument against assumption of risk is based on a costspreading rationale. ${ }^{96}$ According to this argument, firefighters are inadequately compensated through workers' compensation, even though their jobs are more hazardous than most. The Fireman's Rule further disadvantages firefighters by not allowing them to bring an action in tort to make up the difference. ${ }^{97}$

This fourth argument is flawed in that it assumes that firefighters may never bring an action in tort. That is clearly not the case. Firefighters may bring suit against those who negligently fail to disclose hidden or unanticipated dangers. Firefighters may also bring a suit in tort if the nature of the fire has been misrepresented or if the landowner willfully or wantonly injures them. Additionally, they may bring suit if the danger was not one inherent to firefighting.

Furthermore, although this fourth argument against assumption of risk considers only workers' compensation benefits, there are other forms of

95. "The fireman's rule, by allowing negligent persons to escape liability, does not encourage the public to use care in maintaining property and to avoid carelessly starting fires." Fireman's Rule, supra note 92, at 772.

96. For a detailed discussion of the cost-spreading rationale, see infra Part III.C.

97. Fireman's Rule, supra note 92, at 773, states:

The policy of denying recovery to firemen because of the availability of public funds for compensation seems particularly unfair when firemen . . . are compared with other employees. In all cases, the funds may be inadequate to compensate fully for injuries. Although their job risks may be considerably greater than those of the average worker, firemen . . . are unable to bring an action against negligent third parties for uncompensated damages. 
compensation available to firefighters. For example, firefighters are routinely provided with excellent health insurance plans. ${ }^{98}$ Also, firefighters work an average of only about 122 days per year; however, they receive pay comparable to that of the average person who works the standard 255 days per year. ${ }^{99}$ Firefighters are also given pension plans and paid vacations. ${ }^{100}$ Thus, firefighters enjoy many other benefits in addition to workers' compensation. That these payments do not take the form of after-the-fact compensation for injuries by no means decreases their value.

The final argument against the assumption-of-risk rationale is based on the theory that judicial economy is an improper basis for denying recovery, especially when firefighters are denied the opportunity to protect personal rights. ${ }^{101}$ By the same token, since the issue of negligence in starting a fire is frequently litigated and determined in actions by other parties to determine property damage and personal injury, firefighters could easily be made parties to this type of litigation because the issues are the same. ${ }^{102}$

Again, this argument improperly assumes that there is a per se bar to recovery by firefighters. Additionally, at the heart of the above argument is the assumption that firefighters have a personal right to sue for their injuries. As stated previously, in some circumstances firefighters do have a personal right to sue, and they are not denied access to the courts in those

98. See supra text accompanying note 26 .

99. Firefighting is not a "nine-to-five" job. Most firefighters work twenty-four hour shifts with a number of days off in between. One very popular system, the Kelly System, has shifts scheduled as follows: twenty-four hours on duty, twenty-four hours off duty, twentyfour hours on duty, twenty-four hours off duty, twenty-four hours on duty, ninety-six hours (four days) off duty. Another popular system is the Twenty-Four/Forty-Eight System, where the firefighter works twenty-four hours and has the next forty-eight hours off duty. Under both the Kelly System and the Twenty-Four/Forty-Eight System, firefighters work an average of only 122 days per year.

Note that the 255 day per year work schedule of the average worker was calculated by multiplying fifty-one by five. The fifty-one figure represents the number of weeks in a year minus one week for vacation. The five figure represents the number of days in a business work week.

100. Under the Kelly System, if the firefighter takes a vacation day on his last scheduled shift, he will get six days off. Under the Twenty-Four/Forty-Eight System, one day of vacation gives the firefighter five days off. Firefighters are, therefore, much better off than the average person who must take at least three days off work (this figure includes a weekend) to get a comparable vacation.

101. Fireman's Rule, supra note 92, at 773, states:

the fear that allowing injured firemen ... to bring an action against any person whose negligence causes the injury would result in a flood of litigation is also invalid. It violates the basic principle of our legal system that no one should be denied the opportunity to protect personal rights simply to avoid problems of judicial administration.

See also Walters v. Sloan, 571 P.2d 609, 620 (Cal. 1977) (Tobriner, J., dissenting).

102. Walters, 571 P.2d at 620 (Tobriner, J., dissenting). 
situations. However, in other instances, there is no basis for a suit in the first place. ${ }^{103}$ Thus, since firefighters do not have a right to bring suit in the first instance, the legal system is not denying them the opportunity to protect personal rights.

In sum, the assumption-of-risk rationale is an appropriate basis for the Fireman's Rule. Some risks are inherent in firefighting. For injuries resulting from these inherent risks, firefighters should be denied recovery in tort. Unanticipated and hidden dangers, however, should not bar recovery because firefighters cannot be held to assume risks they cannot reasonably foresee. ${ }^{104}$ The assumption-of-risk doctrine provides logical boundaries to the application of the Fireman's Rule and serves as an adequate basis upon which recovery may be barred. ${ }^{105}$

\section{Economic Efficiency}

\section{Self-Insurance and Public Policy}

The final rationale underlying the Fireman's Rule is based upon principles of economic efficiency. ${ }^{106}$ "The fireman's rule reflects the judicial determination that the public has become a self-insurer of its own wrongs. 107 Basically, since it is the public that calls upon firefighters to act, it should be the public that compensates firefighters for their injuries. This rationale reflects the belief that "it [is] too burdensome to charge all who carelessly cause or fail to prevent fires with the injuries suffered by the expert retained with public funds to deal with those inevitable . . occurrences." 108

An important consideration behind the economic rationale is that firefighters are supported by public tax funds to take the risks and incur the injuries inherent to firefighting. Included in this public compensation scheme

103. See, e.g., Pennington v. Stewart, 10 N.E.2d 619 (Ind. 1937) (discussing the personal right to bring suit and due-process jurisprudence).

104. For an extensive analysis of the law regarding realization of risk, see Ernest $\mathbf{H}$. Schopler, Annotation, Modern Status of the Rule Absolving a Possessor of Land of Liability to Those Coming Thereon for Harm Caused by Dangerous Physical Conditions of Which the Injured Party Knew and Realized the Risk, 35 A.L.R.3d 230 (1971 \& Supp. 1997).

105. The following are other cases applying assumption of risk to the Fireman's Rule: City of Redlands v. Sorenson, 221 Cal. Rptr. 728 (Cal. Ct. App. 1985); Sayes v. Pilgrim Manor Nursing Home, Inc., 536 So. $2 d 705$ (La. Ct. App. 1988); Moreno v. Marrs, 695 P.2d 1322 (N.M. Ct. App. 1984); Fiola v. Korman, 592 N.Y.S.2d 429 (N.Y. App. Div. 1993); and Mignone v. Fieldcrest Mills, 556 A.2d 35 (R.I. 1989).

106. See generally Strauss, supra note 53, at 2037.

107. Benjamin K. Riley, The Fireman's Rule: Defining Its Scope Using the CostSpreading Rationale, 71 CAL. L. REv. 218, 219 (1983).

108. Krauth v. Geller, 157 A.2d 129, 131 (N.J. 1960). 
are salary, disability benefits, and retirement benefits. ${ }^{109}$ Furthermore, money paid to firefighters performs two services. First, it is useful for persuading people to become firefighters. Second, it allows the costs of injuries to firefighters to be spread among the tax-paying public. ${ }^{110}$ Injuries to firefighters are inevitable, and under the current cost-spreading scheme, society has established a compensation system that allows the public to act as a self-insurer when firefighters sustain the unavoidable injuries inherent in the profession. ${ }^{11}$ Taxpayers have established a public insurance fund to guarantee that firefighters are compensated for their injuries. The certainty of this system provides peace of mind for both the public and firefighters because all parties know that these funds have been set aside.

Apart from these considerations of efficiency, public policy supports the cost-spreading rationale. Because a workers' compensation system has been established for firefighters, it is not fair to make citizens also pay for their negligence in tort. If this were allowed, the taxpayer would be forced to pay the firefighter twice-once with his tax dollars and again with compensatory damages. ${ }^{112}$ Allowing multiple recoveries for the same injury clearly contradicts public policy. The goal of our compensatory system is to place the injured party in the position in which he or she would have been had the injury not occurred. ${ }^{113}$ Allowing multiple compensatory recoveries for the same injury destroys this basic principle of tort law by granting the injured party a windfall. ${ }^{114}$

109. Riley, supra note 107 , at 235.

110. Id.

111. Id. at 235-36. Regarding this "self-insuring" approach, Riley notes:

The same . . . considerations that support individual private insurance coverage of negligent and reckless conduct support the application of the fireman's rule to that conduct. . . . [T] he ability to anticipate [negligent and reckless] wrongs and protect against them in advance is seen when the public provides a disability and compensation system for its public officers.

Id. at 237.

112. Id. at 236. " [S]ince the public has anticipated negligent and reckless injuries to its officers and has established a scheme to offset the costs of these injuries, it should not be held doubly accountable through liability in tort." Id. at 237. See also Steelman v. Lind, 634 P.2d 666, 667 (Nev. 1981) ("[T] he [fireman's] rule developed from the notion that taxpayers employ firemen . . . to deal with future damages that may result from the taxpayers' own negligence. To allow actions by . . . firemen against negligent taxpayers would subject them to multiple penalties for the protection." ).

113. "[T] he law of torts attempts primarily to put an injured person in a position as nearly as possible equivalent to his position prior to the tort." RESTATEMENT (SECOND) OF TORTS $\S 901 \mathrm{cmt}$. a (1977).

114. See Berko v. Freda, 459 A.2d 663, 666 (N.J. 1983):

Exposing the negligent taxpayer to liability for having summoned the [fire department] would impose upon him multiple burdens for that protection. . . . [T] he taxpayer who pays the fire and police departments to confront the risks occasioned by his own future acts of negligence does not expect to pay again 


\section{Workers' Compensation}

As noted above, a workers' compensation scheme underlies the costspreading rationale. Some opponents of the Fireman's Rule maintain that workers' compensation does not provide an adequate basis for barring recovery in tort by firefighters. Justice Tobriner's dissenting opinions in two court cases put forth this specific argument. ${ }^{115}$ In analyzing the applicability of workers' compensation to firefighters, Justice Tobriner observed that members of the public are no different than third-party tortfeasors in any other action. Justice Tobriner concluded that firefighters should be allowed to sue citizens in tort for their injuries because the workers' compensation system allows tort recovery against third-party tortfeasors. While Justice Tobriner's proposition may seem appealing at first blush, there are compelling reasons why the workers' compensation system provides the better approach.

First, sound reasons exist for treating the public as employers rather than as third-party tortfeasors. "Rather than standing in the shoes of a thirdparty tortfeasor, the public stands in the shoes of the employer who operates a hazardous workplace."116 At least three reasons support this position:

First, fire companies . . . are created by the public to take care of those hazards that individuals inevitably create. Since the public has no need for their services until some danger arises, there is no "workplace", [sic] for these officers except for hazardous ones. . . . Second, ... the fireman's rule will not apply to all injuries that occur while the officer is on duty, but only to those caused by dependent acts of misconduct . . . [; this] places the same limitations on the fireman's rule that the "arising out of and in the scope of employment" test [places] on workers' compensation . . . . Third, . . . the public supports the public officers' disability and compensation scheme through its tax dollars, which are functional equivalents of the workers' compensation insurance premiums that employers pay. ${ }^{117}$

Thus, the parallel to the workers' compensation system is clear. The

when the officer is injured while exposed to those risks. Otherwise, individual citizens would compensate [firefighters] twice: once for risking injury, once for sustaining it.

115. See generally Walters v. Sloan, 571 P.2d 609 (Cal. 1977) (Tobriner, J., dissenting), and Hubbard v. Boelt, 620 P.2d 156 (Cal. 1980) (Tobriner, J., dissenting).

116. Riley, supra note 107, at 239.

117. Id. at 239-40. 
public, like other employers, hires and pays individuals to perform certain tasks. In the case of firefighters, that task is to confront hazards. Accordingly, firefighters will not be allowed recovery if injured by those very hazards. Finally, like other employers, the public pays a premium in the form of tax dollars to insure against these injuries. Therefore, contrary to Justice Tobriner's assertions, there exist very compelling arguments for considering the public as an employer and not a third-party tortfeasor.

\section{Foreseeably Injurious Intentional Acts v. Intentionally Injurious Conduct}

The foregoing discussion does not mean, however, that a firefighter will always be barred recovery in tort. A line must be drawn between two types of conduct that form the boundaries of liability. These types of conduct are foreseeably injurious intentional conduct and intentionally injurious conduct. ${ }^{118}$ As the name implies, intentionally injurious conduct is committed for the purpose of inflicting injury. By contrast, foreseeably injurious intentional conduct lacks the intent to do harm. Both principles involve intentional conduct, but the intended results are wholly different. ${ }^{119}$ With intentionally injurious conduct, the actor intends to commit the act in question and for that act to cause harm to another. An example of an intentionally injurious act is discharging a firearm at a firefighter. Intentionally injurious conduct opens wide the doors to tort liability. The possibility of injury to firefighters reaches unacceptably high levels when this type of conduct is involved..$^{20}$ Just like any type of insurance plan, the Fireman's Rule does not insure against intentionally injurious conduct.

118. See generally Johns-Manville Prod. Corp. v. Superior Court, 612 P.2d 948, 954-55 (Cal. 1980) (announcing the distinctions between foreseeably injurious intentional conduct and intentionally injurious conduct).

119. A useful approach for understanding the difference between these two principles is to draw a parallel to the criminal law classifications of specific and general intent crimes. See SANFORD H. KaDISH \& STEPHEN J. SCHULhOFER, CRIMINAL LAW AND ITS PROCESSES 218 (6th ed. 1995). Specific intent crimes are closely related to intentionally injurious conduct. General intent crimes, on the other hand, are closely related to foreseeably injurious intentional conduct. Examples of these principles in criminal law are breaking and entering and burglary. Breaking and entering only requires that the individual intend to enter another's premises without permission-it is a general intent crime. Similar to the intent present in breaking and entering, the actor committing foreseeably injurious intentional conduct intends only to commit the act in question without intending any further harm. Burglary, on the other hand, takes breaking and entering one step further by requiring that the entrant intend to commit a felony while within the premises. Id. Thus, burglary requires an intent to enter and an intent to commit a felony-it is a specific intent crime. Similarly, the actor committing intentionally injurious conduct intends to commit the act in question and further intends that act to cause harm. For a more in-depth discussion of general and specific crimes, see generally id.

120. Riley, supra note 107, at 244. 
On the other hand, when foreseeably injurious intentional conduct is involved, the actor intends to commit the act but does not intend to hurt anyone by that act-the threat of injury is merely foreseeable and not intentional. An example of foreseeably injurious intentional conduct is when a contractor intentionally builds a cheaply constructed home. Should the home begin to burn, it is foreseeable that injury may result to the responding firefighters from a structural collapse, but such injury is not the contractor's intent.

A farmer burning down an old barn to clear land is another example of foreseeably injurious intentional conduct. The setting of the fire is intentional. The intentional nature of the fire, however, does not change the normal risks associated with fighting the fire. The basic argument is that "fire is fire," no matter what its origin. ${ }^{121}$ Therefore, the firefighter should only be allowed recovery through workers' compensation since the risks that prompted the establishment of public compensation are present in both intentional and accidental fires. ${ }^{122}$

Injuries stemming from intentionally injurious conduct, however, lead to the opposite result. "Intentionally injurious acts . . . present hazards that differ in degree of probable harm." ${ }^{123}$ Firefighters face identical dangers when facing either foreseeably injurious intentional conduct or negligent conduct. "In contrast, . . . since intentionally injurious conduct poses a very high probability of injury, the cost-spreading rationale . . . indicates that the fireman's rule should not bar a private suit." 124 Therefore, "[t]ort liability is not barred . . . where injuries are caused by . . . intentionally injurious conduct ... [because it] represents an unacceptably great and thus uninsurable risk. ${ }^{125}$

\section{The Test for Liability}

The preceding analysis examined two distinct kinds of conduct: one of foreseeably injurious intentional conduct and another of intentionally injurious conduct. In order to determine which applies and whether or not to bar recovery in tort, a court must follow a series of steps. First, the court

121. Id.

122. Id. Riley's example used arson as a foreseeably injurious intentional act. Under Riley's example, the firefighter would be barred recovery since arson is a foreseeably injurious intentional act. But cf. Flowers v. Rock Creek Terrace, 520 A.2d 361 (Md. 1987) (holding arsonists not protected by Fireman's Rule); Grable v. Varela, 564 P.2d 911 (Ariz. 1977) (holding arsonists not protected by Fireman's Rule); Giorgi v. Pacific Gas \& Elec. Co., 72 Cal. Rptr. 119 (Cal. Ct. App. 1968) (suggesting arsonist exception to Fireman's Rule); and Krauth v. Geller, 157 A.2d 129 (N.J. 1960) (suggesting arsonist exception to Fireman's Rule).

123. Riley, supra note 107 , at $244-45$.

124. Id. at 245.

125. Id. at $247-48$. 
must decide if the conduct causing injury was independent or dependent. If firefighters are injured by conduct secondary to that which prompted their response, the conduct is independent. "Since the fireman's rule applies only to those injuries that are dependent on the presence of the officer and thus anticipated through the compensation scheme, the rule should be inapplicable to independent hazards, and the wrongdoer should be liable." 126 "If, on the other hand, the court finds the injury to be caused by the original misconduct, then the cost-spreading rationale . . . appl[ies]."127

Next, the court must determine whether the misconduct in question was intentionally injurious or a foreseeably injurious intentional act. If the act was intentionally injurious, recovery in tort will be allowed. However, if it was only a foreseeably injurious intentional act, recovery will be barred under the Fireman's Rule.

It cannot be denied that the public uses a portion of its tax dollars for self-insurance. Because the public pays for this self-insurance, individual citizens should not be held liable for negligence in starting fires that result in injuries to firefighters. Furthermore, the strong public policy against holding citizens doubly liable for injuries to firefighters adds support to the cost-spreading rationale. Finally, as mentioned previously, intentionally injurious conduct and causes independent of the need for the firefighter's presence give rise to liability in tort, but foreseeably injurious intentional conduct does not.

\section{BRITISH LAW OF OCCUPIERS' LIABIITY TOWARDS FIREFIGHTERS}

\section{A: The Occupiers' Liability Act 1957}

In 1958, British law underwent a transformation regarding its law of occupiers' liability toward land entrants. On January 1 of that year, the Occupiers' Liability Act 1957 went into effect. In general, the Occupiers' Liability Act 1957 regulates the duty that a land occupier owes to his visitors with respect to dangers present upon the premises. ${ }^{128}$

With the passage of the Occupiers' Liability Act 1957, the traditional

126. Id. at 248.

127. Id.

128. For the duty owed to those entering the premises without permission, see the Occupiers' Liability Act, 1984, ch. 3 (Eng.) [hereinafter Occupiers' Liability Act 1984]. The provisions of this Act are pertinent to firefighters who enter a landowner's premises without permission. These provisions, however, impose nearly identical burdens upon the landowner. See generally id. $\S$ (3) to (7). For the sake of efficiency, the Occupiers' Liability Act 1957 will be the statute of reference for this note. For a discussion of the varying liability of landowners, see Jon Holyoak, Occupiers' Liability: Inconsistent Approaches, 85 LAW SOC'Y GAZETTE 19 (1988). 
common law categories of land entrants in Great Britain have been largely abrogated. ${ }^{129}$ The terms "invitee" and "licensee" are no longer terms of art in British law. Under the Act, all lawful visitors are owed the same duty of care. "An occupier of premises owes the same duty, the "common duty of care', [sic] to all his visitors, except in so far as he is free to and does extend, restrict, modify or exclude his duty to any visitor or visitors by agreement or otherwise. ${ }^{n 130}$ The "common duty of care" may be regarded as a duty of care on the part of the land occupier to take all measures necessary under the circumstances to keep the visitor safe while on the occupier's premises. ${ }^{131}$ Thus, the liability of the occupier may be considerably increased under this standard. For instance, even if a social guest has been warned of a danger and nothing wanton or willful has been done by the landowner to injure the guest, the landowner will still be liable if it is determined that it would have been reasonable under the circumstances to correct the problem.

Before considering the possible application of the Fireman's Rule in Great Britain, one must first see how firefighters fit into the current statutory

129. The abrogation of status distinctions of land entrants is not limited to Great Britain. In the landmark case of Rowland v. Christian, 443 P.2d 561 (Cal. 1968), California abrogated status distinctions between all entrants of land, including trespassers. The court stated: "All persons are required to use ordinary care to prevent others being injured as the result of their conduct.' " Id. at 564 (quoting McCall v. Pacific Mail S. S. Co., 55 P. 706, 707 (Cal. 1898)).

The California Supreme Court's reasoning-with the exception of its treatment of trespassers-is similar to that contained in the Occupiers' Liability Act 1957. According to the majority in Rowland:

A man's life or limb does not become less worthy of protection by the law nor a loss less worthy of compensation under the law because he has come upon the land of another without permission or with permission but without a business purpose. Reasonable people do not ordinarily vary their conduct depending upon such matters, and to focus upon the status of the injured party as a trespasser, licensee, or invitee in order to determine the question whether the landowner has a duty of care, is contrary to our modern social mores and humanitarian values. The common law rules obscure rather than illuminate the proper considerations which should govern determination of the question of duty.

Id. at 568. Additionally, the fact that California still employs the Fireman's Rule indicates that the Rule is workable under a scheme, like that in Great Britain, abrogating distinctions of land entrants. For a discussion supporting the abrogation of status distinctions in all American jurisdictions, see Mark J. Welter, Premises Liability: A Proposal to Abrogate the Status Distinctions of 'Trespasser,' 'Licensee' and 'Invitee' as Determinative of a Land Occupier's Duty of. Care Owed to an Entrant, 33 S.D. L. REV. 66 (1987/1988).

130. Occupiers' Liability Act 1957, supra note $12, \S 2(1)$.

131. See id. \$2(2):

The common duty of care is a duty to take such care as in all the circumstances of the case is reasonable to see that the visitor will be reasonably safe in using the premises for the purposes for which he is invited or permitted by the occupier to be there. 
scheme. Under the Occupiers' Liability Act 1957, firefighters are owed the same common duty of care as any other person entering another's property. Still, in light of the wording of the statute, the fact that firefighters are indeed allowed to recover is remarkable. One section of the Act states that "an occupier may expect that a person, in the exercise of his calling, will appreciate and guard against any special risks ordinarily incident to it, so far as the occupier leaves him free to do so. ${ }^{132}$ Another section of the Act states:

[W] here damage is caused to a visitor by a danger of which he had been warned by the occupier, the warning is not to be treated without more as absolving the occupier from liability, unless in all the circumstances it was enough to enable the visitor to be reasonably safe. ${ }^{133}$

In light of the fact that firefighters are experts in the field of firefighting, a landowner's telephone call to the fire authority to report the fire should adequately warn firefighters and put them on notice that hazardous conditions exist. In fact, as experts, firefighters do recognize the dangers inherent to the job; accordingly, they can begin preparing for those hazards the moment they receive the summons for help. Finally, the Act states that "[t]he common duty of care does not impose on an occupier any obligation to a visitor in respect of risks willingly accepted as his by the visitor. ${ }^{n 134}$ Incredibly, this section, along with the two above-mentioned sections, has been held inapplicable to firefighters. As evidenced by these sections, the wording of the Occupiers' Liability Act 1975 is perfectly adapted for excluding recovery by firefighters who sustain injuries from the inherent risks of their calling.

It is difficult to determine why British courts have not focused on the language of the Occupiers' Liability Act 1957. Since the courts have not addressed the issue, there is really no clear basis upon which to form a theory on their failure to consider the Act's exceptions. However, in all likelihood, British courts have avoided explicitly addressing the Act's

132. See id. § 2(3)(b).

133. See id. $\$ 2(4)(a)$.

134. See id. \$2(5). See also Douglas Payne, The Occupiers' Liability Act, 21 MoD. L. REV. 359, 365 (1958):

If the visitor has actual knowledge of a condition by which the occupier excludes his liability his claim might also be barred by section 2 (5) of the Act, which preserves the common law defence of assumption of risk. The effect of a notice excluding liability should, however, be carefully distinguished from the effect of a notice waming a visitor of a danger. The latter . . . will absolve the occupier from liability only if it was enough to enable the visitor to be reasonably safe. 
exceptions in cases involving firefighters because they have instead wished to construe the act in a way that is favorable to firefighters.

Another theory why British courts do not consider the Act's exceptions is that the courts normally may not use legislative history when construing the meaning of legislation. ${ }^{135}$ Because British courts normally cannot refer to legislative history, ${ }^{136}$ they employ a plain-meaning test in interpreting legislation. However, under the plain-meaning test, British courts are on their own in defining the scope of legislative provisions. Accordingly, the courts may actually use the plain-meaning test to interpret provisions however they see fit, rather than to determine the true, plain meaning of a provision. It has been suggested "that courts evade unpopular provisions through interpretation. ${ }^{137}$ Since British courts allowed firefighters to recover under the common law, the courts may regard the exceptions to the Occupiers' Liability Act 1957 as unpopular provisions. They may then attempt to avoid these unpopular provisions by simply interpreting firefighters out of the purview of the exceptions.

"Reliance on individual conceptions of words introduces elements of subjectivity that are inconsistent with many of the justifications for relying on the words alone. This subjectivity threatens the view that judges are simply translating the meaning of the words chosen by the legislature." 138 Subjectivity seems to have played a role in judicial interpretation of the exceptions to the Occupiers' Liability Act 1957. The exceptions to the Act quoted above do not contain language indicating that public safety officers are to be excluded from the Act's exceptions. Indeed, the Act does not contain any provision excluding any person or group from its reach. British courts, then, have independently decided to exclude firefighters from the Act's exceptions by disregarding the plain meaning of the Act.

If British landowners are held to owe firefighters a common duty of care, it is only logical to conclude that firefighters should be subject to the same exceptions as any other person entering another's property. This tradeoff mitigates the burden on landowners by allowing them to escape liability under certain circumstances. As it stands, however, British landowners must bear the burden of a common duty of care toward firefighters without the possibility of mitigation, even though a firefighter may squarely fall within an exception to the Act. Such an anomalous result clearly contravenes the spirit of the Occupiers' Liability Act 1957.

135. See generally Robert G. Vaughn, A Comparative Analysis of the Influence of Legislative History on Judicial Decision-Making and Legislation, 7 IND. INT'L \& COMP. L. REV. 1 (1996).

136. Id. at 6.

137. Id. at 58 .

138. Id. at 21 . 


\section{B. Great Britain's Failure to Adopt the Fireman's Rule}

Although the Fireman's Rule is almost universally applied in the United States, Great Britain has never applied the Rule. In determining landowners' liability with respect to firefighters, British courts have looked to the foreseeability of the firefighters' response and the foreseeability of injuries to the firefighters under the circumstances. In Great Britain, foreseeability establishes the landowner's duty of care. However, British courts also consider other factors that are the same as those found in negligence cases in the United States: proximate causation and actual harm.

First, a number of British cases have discussed the duty owed a firefighter (or police officer) by a land occupier. The more recent cases include Sibbald $v$. Sher Brothers, ${ }^{139}$ Salmon v. Seafarers Restaurant Ltd., ${ }^{140}$ Ogwo v. Taylor, ${ }^{141}$ and Hibbert v. John Blundell Ltd. ${ }^{142}$ Two cases not involving firefighters are also relevant to this discussion. They are Haynes v. Harwood ${ }^{143}$ and Chadwick v. British Transport Commission. ${ }^{144}$

\section{Sibbald v. Sher Brothers}

In Sibbald, a firefighter's wife brought suit to recover for the death of her husband who was killed in the line of duty while fighting a fire in a warehouse. As the fire blazed, an untreated hardboard ceiling erupted into flames thereby blocking several firefighters' exit. As a result, seven firefighters were killed. Lord Fraser found in favor of the defendantlandowners. He held that it is too great a burden to require landowners to ensure that adequate means of access to and from the building will exist for the duration of the fire. ${ }^{145}$

At first blush, Lord Fraser's reasoning looks very close to that underlying the Fireman's Rule. Yet, the two are not the same. The sui generis basis of the Fireman's Rule ${ }^{146}$ deals only with the efficiency of

139. Sibbald v. Sher Brothers, (H.L. 1980), Transcript [hereinafter Sibbald Transcript]. 140. [1983] 3 All E.R. 729 (Q.B.).

141. [1987] 3 All E.R. 961 (H.L.).

142. Hibbert v. John Blundell Lid., (C.A. 1995), Transcript [hereinafter Hibbert Transcript].

143. [1934] 1 K.B. 146 (C.A.) (involving police constable).

144. [1967] 2 All E.R. 945 (Q.B.) (involving private citizen engaged in rescue).

For a discussion of recovery for psychiatric injuries suffered by a police officer as the result of his employer's negligence, see Frost v. Chief Constable of the South Yorkshire Police [1997] 1 All E.R. 540 (C.A.). See also Page v. Smith [1995] 2 All E.R. 736 (H.L.) (declaring the standard for recovering for psychiatric injury).

145. Sibbald Transcript, supra note 139, at 4.

146. The sui generis theory is discussed in detail and adopted as the appropriate land entrant categorization of firefighters in Part III.A, supra. 
requiring the occupier to keep his or her premises safe before and at the arrival of the fire units. Sibbald, on the other hand, dealt only with the feasibility of requiring sufficient access and egress for the period after the arrival of fire units. The Sibbald opinion never discussed the obligations of the occupier with respect to adequate access for firefighters upon their arrival. Because the Fireman's Rule was not even an issue in Sibbald, that case was not an affirmation of the Fireman's Rule.

\section{Salmon v. Seafarers Restaurant Ltd. ${ }^{147}$}

In Salmon, the plaintiff-firefighter was injured while fighting a fire at a restaurant. While the plaintiff was stabilizing a ladder used to gain access to the second story of the building, heat melted the seals on some gas meters causing an explosion that threw the plaintiff to the ground. The court ruled in favor of the plaintiff-firefighter. It was held that the landowner, who caused the fire, owed a duty to the firefighter that extended to the ordinary and inherent risks of firefighting and was not limited to only special, exceptional, or additional risks. ${ }^{148}$ The landowner argued that the firefighter's special skills and training were relevant in determining liability. However, the court found that where it was foreseeable that a firefighter exercising those skills could nevertheless be injured, the occupier was in breach of his duty of care ${ }^{149}$ In essence, the court determined that since the fire was caused by the defendant's negligence and since it was foreseeable that the plaintiff would be required to attend the fire and would be at risk for the type of injuries he received, the defendant was liable in tort for those injuries. ${ }^{150}$

\section{Ogwo v. Taylor ${ }^{151}$}

In $O g w o$, the defendant-landowner was removing paint from his house with a blowtorch when the house caught on fire. The plaintiff-firefighter entered the attic to attack the fire. When the water from the plaintiff's hose made contact with the fire, intense steam was produced. Since this was an attic fire, the fire was in an enclosed area and the steam had no means of

147. [1983] 3 All E.R. 729 (Q.B.). For an examination of this case and exceptional hazards, see Jon Holyoak, Occupiers' Liability to Firemen, 84 LAW SOc'Y GAZETTE 964, 965 (1987).

148. [1983] 3 All E.R. at 733.

149. Id. at $735-36$.

150. Id. at 736.

151. [1987] 3 All E.R. 961 (H.L.). For a brief discussion of this case and predictable damage, see Holyoak, supra note 147, at 966. 
escape. As a result, the plaintiff suffered serious burns. ${ }^{152}$ Lord Bridge stated that it was predictable that the fire brigade would be called and that a firefighter might be injured despite all his skills and protective clothing. ${ }^{153}$ The only issue was whether liability would attach to an injury caused by steam. It was held that this was the same type of damage that would result from contact with flames and that it could be the subject of a claim. ${ }^{154}$

The defendant argued that no duty was owed since the plaintiff must be taken to bear the ordinary risks of his calling. ${ }^{155}$ In essence, the defendant was arguing the assumption-of-risk theory that underlies the Fireman's Rule. In rejecting the defendant's argument, Lord Bridge declared: "I am left in no doubt whatever that the American 'fireman's rule' has no place in British law." 156

\section{Hibbert v. John Blundell Ltd.}

In this case, a plaintiff-firefighter was passing through a smoke-filled structure where the floor was wet and slippery. The plaintiff slipped on the wet floor and collided into his partner, causing serious injury to his own wrist. It was determined that in order to fall, the plaintiff must have departed from a standard procedure known as the "shuffle method," which is specifically designed to keep firefighters from slipping on wet floors. ${ }^{157}$

In Hibbert, Lord Beldam analyzed proximate causation. In Lord Beldam's opinion, simply because some other cause intervenes in no way means that the initial cause is not the proximate cause. ${ }^{158}$ He proceeded to determine that the negligence of the defendant-landowner's servants was the proximate cause of the plaintiff's injuries. ${ }^{159}$ But for the servants' negligence in starting the fire, the plaintiff would not have been at the premises and

152. While one may believe that a firefighter's protective clothing would guard against burns from water, the scalding hot steam can, and often does, penetrate the protective materials.

153. [1987] 3 All E.R. at 966.

154. Id. at 964.

155. Id.

156. Id. at 966.

157. Hibbert Transcript, supra note 142, at 61.

158. Beldam's actual words were:

What does 'proximate' here mean? To treat proximate cause as if it was the cause which is proximate in time is ... out of the question. The cause which is truly proximate is that which is proximate in efficiency. That efficiency may have been preserved although other causes may meantime have sprung up which culminate in a result of which it still remains the real efficient cause to which it can be ascribed.

Id. at 64 (quoting Leyland Shipping Co. Ltd. v. Norwich Fire Ins. Soc'y Ltd. [1918] App. Cas. 350, 369 (H.L.)).

159. Id. 
would not have slipped on the wet floor. The fact that the plaintiff momentarily departed from the prescribed method of passing through the structure did not break the chain of causation. ${ }^{160}$

Lord Beldam also found, however, that the firefighter contributed to his own injuries. Accordingly, Lord Beldam attributed fifty percent of the fault to the plaintiff. ${ }^{161}$ Using similar reasoning, the only other judge on the panel, Lord Ward, found a causal connection between the injuries and both the defendant's and the firefighter's conduct. He too apportioned fault between the parties at fifty-fifty. ${ }^{162}$

Hibbert, however, does not undermine the assumption-of-risk basis for the Fireman's Rule. This case barred a portion of the plaintiff-firefighter's recovery on the basis of comparative fault. To conclude that this indicates a willingness of British courts to apply the Fireman's Rule is to misunderstand the very foundation of the Rule. The purpose of the Fireman's Rule is not to bar recovery under a theory of comparative fault; indeed the Fireman's Rule does not contemplate the impact of a firefighter's conduct upon his ability to recover. Rather, the Fireman's Rule is concerned with the conduct of the party who started the fire. If the firefighter's injuries were caused by a defendant's independent act of negligence, then the firefighter's comparative fault is a proper subject of inquiry; in that scenario, though, the Fireman's Rule does not apply in the first instance because the injury is not caused by the negligently started fire, but by some other act of the defendant. In a case where the Fireman's Rule applies, the comparative fault of the firefighter is immaterial because he will be barred recovery regardless of his conduct. Thus, the reasoning employed in Hibbert does not even implicate the Fireman's Rule.

\section{Haynes v. Harwood}

Although Haynes v. Harwood did not involve a firefighter, it is still informative in the analysis of British policy. In Haynes, the plaintiff-police constable was injured while stopping a team of runaway horses. The case was decided in favor of the plaintiff-police constable. Greer, L.J., held that

160. Beldam stated:

So here the chain of causation between the floor becoming slippery and the negligence of the defendants' servants in starting the fire was intact. It was not, in my view, broken or rendered inoperative by the momentary failure of the appellant [firefighter] to follow the shuffle method of advancing up this slippery floor, nor could such a lapse of concentration be characterised as foolhardy exposure to unnecessary risk.

Id.

161. Id. at 65 .

162. Id. at 67. 
the defendant's servant failed "to use reasonable care for the safety of those who were lawfully using the highway in which this van with the two horses attached was left unattended. ${ }^{163}$

The court in Haynes considered the doctrine of novus actus interveniens, meaning "new intervening act." Testimony established that a boy had thrown a rock at the horses, causing them to bolt. According to the opinion, if the novus actus interveniens is exactly what one would expect to happen by leaving horses unattended, then it may not be used as a defense. ${ }^{164}$ "[] $t$ is only a step in the way of proving that the damage is the result of the wrongful act." 165 Thus, the boy's act failed to mitigate the defendant's conduct. Additionally, the court examined assumption of risk. The court held that assumption of risk does not apply in a case where an individual has placed himself in peril in order to save another person from the danger of personal injury or death. ${ }^{166}$ Thus, the fact that the victim was a police officer who had voluntarily undertaken a duty to protect the citizens of his community was irrelevant because he had attempted to rescue a person from personal injury or death.

\section{Chadwick v. British Transport Commission}

Although Chadwick involved a civilian rescuer, it is relevant to this discussion because the same law is applied to both civilian and professional rescuers in Great Britain. In Chadwick, an accident involving two trains killed ninety people and trapped several more in the wreckage. The plaintiff sought to help the victims. As a result of the rescue, the plaintiff suffered mental shock for which he sought compensation.

Judge Waller decided that the defendant train companies were negligent for allowing two trains to collide. ${ }^{167}$ The foreseeable result of this negligence was that the passengers would be placed in danger. ${ }^{168}$ People would foreseeably attempt to rescue the victims, and some of the rescuers would

163. Haynes v. Harwood [1934] 1 K.B. 146, 153 (C.A.).

164. Id. at 156.

165. Id. In concluding this point, Greer stated:

There can be no doubt in this case that the damage was the result of the wrongful act in the sense of being one of the natural and probable consequences of the wrongful act. It is not necessary to show that this particular accident and this particular damage were probable; it is sufficient if the accident is of a class that might well be anticipated as one of the reasonable and probable results of the wrongful act.

Id.

166. Id. at 157.

167. [1967] 2 All E.R. at 951.

168. Id. at 952. 
thereby incur injury. ${ }^{169}$ Since it was foreseeable that rescuers would be injured as a result of the defendants' negligence, the defendants were held liable for the plaintiff's injuries. ${ }^{170}$

Because Judge Waller emphasized the status of the plaintiff as simply a rescuer, his analysis applies with equal force to a professional rescuer. Indeed, the methodology employed by Judge Waller was followed closely by Lord Bridge in $O g w o,{ }^{171}$ which did involve a professional rescuer. The fact that the courts do not separate rescuers as either professional or civilian means that the result in Chadwick would have been the same if the plaintiff had been a professional rescuer.

British courts have not focused upon the unique nature of firefighting. Nor have they considered a firefighter's voluntary decision to undertake the risks inherent in the calling, a firefighter's right to enter property, or a firefighter's expertise in dealing with the hazards of fire. ${ }^{12}$ The British approach, therefore, runs counter to the fundamental principles of the Fireman's Rule as applied in the United States. As will be demonstrated below, the American approach to liability is ultimately the better approach. ${ }^{173}$

\section{EXTENDING THE FIREMAN's RULE to GREAT BRTTAIN}

To see how the Fireman's Rule would work in Great Britain, it is useful to apply the principles of sui generis status, assumption of risk, and economic efficiency to the facts of existing British case law. ${ }^{174}$ The application of these three principles to British case law demonstrates not only that the Fireman's Rule is a workable alternative in Great Britain, but also that it is a desirable approach to the determination of landowners' liability with respect to firefighters.

\section{A. Status of Firefighters as Sui Generis Entrants on Land ${ }^{175}$}

In Great Britain, firefighters clearly are sui generis entrants on land. In fact, a British statute grants firefighters the same authority to enter an individual's premises as American firefighters are granted in the United

169. Id.

170. For further discussion of liability and foreseeable victims, see S.P. Broome, $A$ Skiver's Charter?, 137 NEW L.J. 1201 (1987).

171. See generally [1987] 3 All E.R. 961 (considering the foreseeability of the response of rescuers and the foreseeability that some of those rescuers would be injured).

172. For a discussion of the argument that firefighters are not foreseeable plaintiffs because of their training and experience, see Holyoak, supra note 147, at 967.

173. See infra Part V.

174. See supra Part III.

175. Note that Haynes and Chadwick will not be discussed under this subsection because the plaintiffs in those cases were not injured on private premises. 
States. ${ }^{176}$ Furthermore, as is also the case under American law, anyone who interferes with British firefighters while they are executing their duties may be held liable. ${ }^{177}$ Thus, British landowners are held just as powerless to exclude firefighters from their premises as are American landowners. Because British firefighters occupy a status sui generis, landowners should only owe the firefighters a duty to warn of known, hidden dangers and to refrain from wantonly or willfully injuring the firefighters. Existing British case law may be used to demonstrate this proposition.

In Sibbald, the firefighter would have been denied recovery under the sui generis theory. When the fire occurred, it was not known by the landowner that untreated hardboard could suddenly ignite and become engulfed in flames. ${ }^{178}$ The landowner, therefore, should not be held liable for failing to alert the firefighters of a hidden danger, because there was no way for the landowner to know that the ceiling would erupt into flames. ${ }^{179}$ Furthermore, the landowner did not wantonly or willfully injure the firefighters. The firefighters simply had the misfortune of being in the room that was overcome by flames. Considering these factors, and the fact that the landowner could not exclude the firefighters, the firefighters were properly denied recovery in tort.

Although the result is the same under both the sui generis theory and the court's theory, the two theories are based on wholly different grounds. The Sibbald court reached its conclusion in light of the burden that would be placed on landowners if they were required to keep entrances and exits open for firefighters after their arrival on the scene. The sui generis theory, on the other hand, considers only the burden of providing adequate access prior

176. Fire Services Act, 1947, 10 \& 11 Geo. 6, ch. $41, \S 30$ (1) (Eng.). The Fire Services Act 1947 states:

Any member of a fire brigade maintained in pursuance of this Act who is on duty, any member of any other fire brigade who is acting in pursuance of any arrangements made under this Act, or any constable, may enter and if necessary break into any premises or place in which a fire has or is reasonably believed to have broken out, or any premises or place which it is necessary to enter for the purposes of extinguishing a fire or of protecting the premises or place from acts done for firefighting purposes, without the consent of the owner or occupier thereof, and may do all such things as he may deem necessary for extinguishing the fire or for protecting from fire, or from acts done as aforesaid, any such premises or place or for rescuing any person or property therein.

Id. (emphasis added).

177. Id. §30(2) ("Any person who willfully obstructs or interferes with any member of a fire brigade maintained in pursuance of this Act who is engaged in operations for firefighting purposes shall be liable on summary conviction to a fine ....").

178. Sibbald Transcript, supra note 139, at 48.

179. For an American parallel, see Buren v. Midwest Indus., Inc., 380 S.W.2d 96, 98-99 (Ky. Ct. App. 1964) (holding that condition of premises causing fire to spread rapidly was not actionable). 
to the arrival of the firefighters; after that point, the firefighters officially take over the premises. This "firefighter takeover" is perfectly appropriate. Firefighters know how to maintain adequate modes of access and egress. A civilian trying to keep the entrances and exits clear would only get in the way. Plus, firefighters may enter the structure by various means (e.g., windows or even holes in walls), which would make it difficult for a landowner to anticipate what openings need to remain safe for entrance and exit. Thus, the more persuasive basis for the result in Sibbald is that because the landowner did not fail to warn of a danger of which he knew, did not wantonly or willfully injure the firefighters, and could not do anything to exclude the firefighters since they entered his property out of a right granted by law, the firefighters are of a class sui generis, and the landowner should not be held liable for their deaths.

The same result may be reached in Salmon, Ogwo, and Hibbert. In none of those cases did the landowner fail to warn of a danger. In Salmon, the firefighter must have known that gas mains were present since the fire occurred at a restaurant, which very predictably used gas. Furthermore, the firefighter must have known that exposure to heat could cause the mains to rupture. Therefore, if the firefighter knew that the mains were present and that they could explode, then the landowner did not fail to warn of a hidden danger since the firefighter, through his expertise, must be taken to recognize those types of hazards. As such, the hazards were not hidden and the landowner had no duty to warn of them.

In $O g w o$, the danger of sustaining a steam injury was not hidden. Anytime a fire is fought with water, steam will be emitted. In Ogwo, not only was the firefighter spraying water onto the fire, but he was also spraying the water in a confined space. That considerable steam production in a confined space will increase the potential for steam burns is not surprising. Firefighters, who are experts in dealing with the hazards of fire, must therefore realize that producing large amounts of steam in a confined area will result in the area filling with hot vapors that may cause burns. Thus, the landowner had no duty to warn the firefighter of the potential for injury from steam. Furthermore, the landowner did not willfully or wantonly injure the firefighter. The steam production resulted from the firefighter's actions, not from those of the landowner. The steam was simply the natural result of placing water in an environment of considerable heat. Therefore, since the landowner had no duty to warn the firefighter of the danger of steam and did not willfully or wantonly injure the firefighter, the landowner cannot be held liable for the firefighter's injuries.

The sui generis theory applies with equal force to Hibbert. That wet tile is slick is a basic physical principle. Of all people, firefighters should recognize this obvious hazard since they routinely work around wet 
surfaces. ${ }^{180}$ The threat of slipping on wet surfaces is a routine hazard of which firefighters should be aware. Furthermore, in Hibbert, the firefighter's injuries did not result from wanton or willful conduct by the landowner. The landowner did not spray the water on the tiles, and he certainly had no duty to mop up the water or to warn the firefighters of the water's presence before the firefighters passed along the slick surface. The injuries sustained were simply the result of the plaintiff-firefighter's decision to depart from the prescribed manner of walking on wet surfaces; thus, the landowner should not have been held liable since he neither failed to warn of a hidden danger nor acted willfully or wantonly.

In Sibbald, Salmon, Ogwo, and Hibbert, the firefighters entered the landowners' premises out of a right conferred upon them by law. The landowners were held powerless to do anything to protect the firefighters since interference with fire-scene operations may result in criminal liability. Additionally, the actual responses of the firefighters could not have been predicted ahead of time. Without the Fireman's Rule, the landowner may be held liable for failing to prepare properly for their arrival. In all of these cases, the firefighters were sui generis, and the landowners should have been held liable only if they failed to warn of a hidden danger or if they wantonly or willfully injured the firefighters while they were executing their duties. In none of these four cases was either basis for liability present, and the firefighters should have been denied recovery.

\section{B. Assumption of Risk}

The doctrine of assumption of risk provides another basis for denying recovery to British firefighters. The very language of the Occupiers' Liability Act 1957 protects the occupier from liability when the entrant fails to guard against risks inherent to his calling. ${ }^{181}$ Additionally, the Act provides that landowners shall be shielded from liability if they warn the entrant of the danger and such warning is enough to make the entrant reasonably safe. ${ }^{182}$ The Act also provides that landowners do not have to guard against risks that the entrant willingly confronts. ${ }^{183}$ Amazingly, these standards have never been applied to firefighters in Great Britain. Given its language, the Act clearly provides a basis for applying assumption of risk to British firefighters. Additionally, British tort law follows the common law

180. This argument is strengthened when one considers that the firefighters in Hibbert were taught a special method of walking, discussed supra in Part IV.B.4, to combat this type of hazard.

181. See Occupiers' Liability Act 1957, supra note 12, § 2(3)(b).

182. See id. \$2(4)(a).

183. See id. § 2(5). 
doctrine of volenti non fit injuria, ${ }^{184}$ which means that one who has consented to an injury may not be heard later to complain. ${ }^{185}$ Accordingly, the American common law doctrine of assumption of risk may be easily applied to existing British case law involving injuries to firefighters.

The threat of the rapid spread of fire in Sibbald was no doubt a risk inherent to firefighting. ${ }^{186}$ Nonetheless, the firefighters willingly chose to confront the possibility that more fire would erupt. Furthermore, the defendant did not interfere with the firefighters while they executed their duties; instead, he left them free to do their job. Thus, the firefighters should have been barred recovery under both common law assumption of risk and the Occupiers' Liability Act 1957.

The Salmon case lends itself to a similar analysis. Restaurants routinely have gas lines for cooking and heating purposes. Accordingly, firefighters should be aware that gas mains will be present at a restaurant fire. Anytime gas is being used on a premises, there is an inherent threat that it will cause an explosion if exposed to heat. Knowing that the gas mains could potentially explode, the plaintiff in Salmon willingly confronted that hazard and began climbing a ladder. The firefighter, therefore, willingly confronted the inherent risk of explosion. Moreover, the defendant-landowner did not interfere with the plaintiff-firefighter in any way. Given the fact that the threat of explosion must have been realized, that the firefighter willingly confronted it anyway, and that the landowner left the firefighter to do his job, the firefighter assumed the risk of explosion. Thus, under the plain wording of the Occupiers' Liability Act 1957 and common law assumption of risk, the landowner should have been protected from liability.

The plaintiff-firefighter in $O g w o$ also assumed the risk of injury. One does not need to be a firefighter to realize that steam causes burns. The risk of steam burns is particularly high in firefighting because anytime a fire is fought, tremendous amounts of steam are generated. In Ogwo, the firefighter should have been especially aware of the risk of steam burns because he was fighting the fire in a confined space, which makes being burned even more likely since the steam has only limited means of escape. Again, the landowner in this case left the firefighter free to do his job.

184. For a discussion of the doctrine of volenti non fit injuria, see Morris v. Murray \& Anor, 140 NEW L.J. 1459 (1990), and Syvil Lloyd-Morris, The Age of Consent, 141 NEW L.J. 426 (1991).

185. For an in-depth discussion of a variety of topics related to this doctrine (e.g., volenti non fit injuria, ex turpi causa, and contributory negligence), see Kevin Williams, The Wrongdoing Passenger, 140 NEW L.J. 1235 (1990).

186. Several factors, such as wind, dryness, and building materials disposed to rapid burning, are frequent causes of the accelerated spread of fire. These risks are not uncommon in fighting fire and firefighters should be held to realize these inherent risks. 
Given all of these factors, the firefighter's claim should have been barred under both the Occupiers' Liability Act 1957 and common law assumption of risk.

As for the Hibbert case, slipping on a wet floor is an inherent risk of firefighting. ${ }^{187}$ The plaintiff-a firefighter who had been taught the "shuffle method"-must have realized the inherent risk of slipping. In light of the fact that the defendant-landowner had not interfered with the plaintiff's performance of his job, that the plaintiff had been taught a special method of walking on wet tiles, that such a risk of injury is inherent in firefighting, and that the plaintiff willingly confronted such danger anyway, his claim should have been barred by assumption of risk and the Occupiers' Liability Act 1957.

In Haynes, the dangers of attempting to stop the horses were open and obvious. There is an obvious threat of being trampled or run over by the coach in an attempt to stop a team of runaway horses. The officer, nonetheless, willingly confronted the inherent dangers of attempting to stop the horses. Since the officer must have realized the dangers inherent in this attempted maneuver and nevertheless voluntarily confronted those dangers, his suit should have been barred by assumption of risk. ${ }^{188}$

Unlike the plaintiffs in the previous cases, the plaintiff-rescuer in Chadwick was properly allowed recovery. It was not the plaintiff's calling to confront the gruesome nature of mass casualty incidents. He was simply a citizen attempting to lend a hand to others in need. Given the fact that the plaintiff was not employed to confront these types of hazards, he does not fall within the purview of the Fireman's Rule. Instead, the plaintiff is protected by what is known as the rescue principle. ${ }^{189}$ Under the rescue principle, ${ }^{190}$ the rescuer is regarded as a foreseeable plaintiff when the

187. The inherent nature of this risk is further evidenced by the fact that the fire brigade, realizing the potential for slipping on wet floors, taught firefighters the "shuffle method" to combat the risk of slipping.

188. Note that the Occupiers' Liability Act 1957 was not in effect when Haynes was decided. Nonetheless, the Act would not have been applied in Haynes even if it had existed because the officer was injured on a public street, not a private premises.

189. Note that this principle applies only to the amateur rescuer. The Fireman's Rule is an exception to this principle since it takes into account the unique character of the calling of public safety officers. The basic line that can be drawn to justify this distinction is that the average citizen is not expected to confront the hazards of rescue while the firefighter or police officer is. Furthermore, amateur rescuers have not received the extensive training provided to professional safety officers. As such, they cannot be held to realize all the dangers to which they may be exposed during a rescue effort. Additionally, the experience of professional safety officers allows them to keep a level head during tense rescue situations, thereby giving them an opportunity to survey the situation and recognize the risks involved. The amateur rescuer, on the other hand, cannot be expected to remain calm under the circumstances of an emergency rescue.

190. See also Solgaard v. Guy F. Atkinson Co., 491 P.2d 821, 825 (Cal. 1971) (holding 
defendant negligently causes the occasion for rescue. ${ }^{191}$ Accordingly, the injured rescuer may recover in tort for his injuries resulting from the defendant's negligence. ${ }^{192}$

In Chadwick, the defendant negligently operated its train. It was foreseeable that the train accident would result in injuries to, at the very least, the passengers on the train. The accident, therefore, foreseeably caused the occasion for rescue. The plaintiff in Chadwick, recognizing the occasion for rescue, began rescuing injured passengers. His injuries were the foreseeable result of the defendant's negligence, and he was properly allowed recovery under the rescue principle.

In summary, it is clear that the firefighters and police officer involved in these British cases should have been denied recovery on the basis of assumption of risk. In none of these cases was the plaintiff exposed to risks that were not inherent to his work. Indeed, the risks involved in these cases were basic to the operations undertaken. Furthermore, in none of the cases did the landowner interfere with the operations of the public safety officers. Finally, with full knowledge of the dangers inherent in those operations, the public safety officers willingly confronted the hazards. The only logical conclusion that can be drawn from these circumstances is that the plaintiffs assumed the risk of injury, and the British citizens should not have been held liable to them for risks knowingly and voluntarily encountered.

\section{Economic Efficiency}

The final basis for applying the Fireman's Rule to Great Britain is the cost-spreading rationale. Application of the cost-spreading rationale to British firefighters is both logical and efficient. To demonstrate this point,

that the rescue principle varies the ordinary rules of negligence in two respects: first, the rescuer can sue on account of defendant's negligence toward the party rescued rather than negligence toward the rescuer himself; and, second, it restricts the availability of the defense of contributory negligence by making the defendant prove the rescuer acted rashly or recklessly).

191. For a discussion of the applicability of the rescue principle in both Great Britain and the United States, see J. Tiley, The Rescue Principle, 30 MoD. L. REv. 25 (1967).

192. See Wagner v. International Ry. Co., 133 N.E. 437 (N.Y. 1921). In this famous decision, Justice Cardozo explained the rescue principle:

Danger invites rescue. The cry of distress is the summons to relief. The law does not ignore these reactions of the mind in tracing conduct to its consequences. It recognizes them as normal. It places their effects within the range of the natural and probable. The wrong that imperils life is a wrong to the imperiled victim; it is a wrong also to his rescuer. . . . The risk of rescue, if only it be not wanton, is born of the occasion. The emergency begets the man. The wrongdoer may not have foreseen the coming of a deliverer. He is accountable as if he had.

Id. at 437-38. 
the following discussion examines the six British cases discussed in the preceding subsections.

The cases of Sibbald, Salmon, Ogwo, Hibbert, and Haynes may be treated summarily. Each of these cases involves professional public safety officers injured during the execution of their duties. ${ }^{193}$ As such, since each plaintiff is a public safety officer, each is covered by the same public compensation system.

Similar to the United States, Great Britain has established a system of public compensation for firefighters. The publicly-funded system allows the citizens of Great Britain to act as self-insurers. Firefighting in Great Britain is no doubt as inherently dangerous as it is in the United States. British citizens, therefore, have foreseen that no matter what measures are taken, firefighters will be injured during the course of their duties. In an effort to combat these inevitable injuries, British citizens provide compensation to their firefighters in order to persuade them to undertake the hazardous calling, as well as to compensate firefighters for injuries sustained on the job.

Like the American compensatory system, which seeks to place the individual in the position he or she would have been in had injury not occurred, the British compensatory system should compensate for the injury at hand and nothing more. British firefighters, like American firefighters, may recover for line-of-duty injuries from a publicly-funded compensation scheme for injuries and ill health. ${ }^{194}$ As it stands, however, the British firefighter also can recover for injuries in tort. ${ }^{195}$ This system of double recovery runs counter to the very purpose of the compensatory system. It provides the firefighter with a windfall and charges the citizen twice for the same job. No citizen injured by a negligently constructed product would be justified in recovering for his injuries from both the dealer of the product as well as from the manufacturer. The individual would be required to seek compensation from one party or the other or from some combination of the two. Recovering a judgment from both parties individually is repugnant to the compensatory system-yet that is exactly what British law allows firefighters to do. Under the British system, firefighters recover once from a citizen through tax-based compensation and again through a privately-

193. As a reminder, Sibbald, Salmon, Ogwo, and Hibbert involved firefighters, Haynes involved a police constable, and Chadwick involved a civilian.

194. Firemens' Pension Scheme, S.I. 1992, No. 129 [hereinafter Firemens' Pension Scheme]. Schedule 2, part B3 provides for an ill-health award, and schedule 2, part B4 provides for an injury award that allows recovery "if the infirmity was occasioned by a qualifying injury." Id. at sched. 2, pt. B4.

A qualifying injury is defined as "an injury received by a person without his own default in the execution of his duties as a regular firefighter." Id. at sched. 2, pt. A9. "An injury shall be treated as having been received by a person without his default unless the injury is wholly or mainly due to his own serious and culpable negligence or misconduct." Id.

195. See supra text accompanying note 194; see generally supra Part IV. 
funded tort judgment. The practice of allowing firefighters to recover twice for these injuries removes the incentive for maintaining workers' compensation and paves the way for grave economic inefficiency. More importantly, allowing this type of compensation promotes double recovery in its most basic form and violates the fundamental principles underlying the compensatory system.

Firefighters are also provided with pensions. ${ }^{19}$ These pensions are funded through both contributions of firefighters and of the fire authority, which is funded by the British public. ${ }^{197}$ Pensions are a wonderful means for firefighters to plan for their retirement. ${ }^{198}$ The financial security associated with a pension is tremendous. Pensions provide for both financial and mental security, and British firefighters, therefore, receive a considerable benefit from the tax money set aside for their financial stability after leaving the fire service. ${ }^{199}$ These pensions are another powerful example of firefighter compensation provided extensively by the public purse.

The plaintiffs in Sibbald, Salmon, Ogwo, Hibbert, and Haynes were all covered by the above-discussed public funds. Thus, compensation for the risk of the plaintiffs' injuries and for the injuries themselves had already been contemplated and provided. As such, all of these plaintiffs should have been barred recovery in tort under the cost-spreading rationale.

Chadwick provides quite a different perspective on the preceding discussion. The plaintiff in Chadwick was not a professional rescuer of any sort; he received no salary provided by public funds. He was not eligible for

196. See generally Firemens' Pension Scheme, supra note 194 (setting forth the parameters for coverage, payment systems, and types of recovery allowed).

197. See Gov't ACtuary's DEP'T (GREAT Britain), MaIN FEatures of THE FIREFIGHTERS' PENSION SCHEME at Annex B (1996) (stating that British firefighters must pay eleven percent of each check into the pension scheme).

198. Firemens' Pension Scheme, supra note 194, at sched. 2, pt. B1, lays the foundation for the ordinary pension. This pension allows pension payments to be recovered by a retired firefighter who has attained the age of fifty and has at least twenty-five years of pensionable service provided he has not become entitled to an ill-health award. Id.

199. The following are brief descriptions of the other pensions available to firefighters. Schedule 2, part B2 of the Firemens' Pension Scheme establishes a short service award. This provision allows the recovery of a limited pension by a firefighter required to retire because of a mandatory retirement age limitation or who has attained the age of sixty-five. Id. He is entitled to at least two years pensionable service if not entitled to any additional recovery under any other provision of part B. Id. Schedule 2, part B5 of the Firemens' Pension Scheme provides for a deferred pension. A deferred pension basically allows a firefighter not serving until retiring age to recover a pension for the time he did serve beginning on his sixtieth birthday, or on an earlier date if he becomes permanently disabled. Id. Finally, schedule 2, part B6 provides for repayment of aggregate pension contributions. Generally, this provision allows a firefighter, who quits one fire brigade to work for another or who decides to stop paying into his own pension fund, to recover the aggregate contributions he has made into his fund prior to his leaving the employment of that fire brigade. Id. 
workers' compensation benefits for his injuries because they were unrelated to his employment. Finally, his post-employment financial well-being was not secured through public funds in the form of a pension. Considering his status as a civilian rescuer, the plaintiff in Chadwick was justified in recovering in tort for his injuries. Since he was neither employed nor compensated by the public, the only recourse available to him to recover for his injuries caused by the negligence of another was through the courts. The Chadwick scenario is precisely the type of situation for which the tort system was established.

The injustice of Great Britain's compensation system becomes especially apparent when Chadwick is compared to the other five cases. Chadwick had no obligation to help the victims of the train accident. Nonetheless, he undertook to help his fellow citizens in a time of great tragedy and need. For his injuries, he was placed in the position he would have been in had the accident not occurred. Like Chadwick, the public safety officers in the other five cases undertook rescues. However, it is the firefighter's and police officer's job to encounter these situations. Yet when they were injured, they received compensation from both the public and the private citizen. Thus, professional safety officers, whose very job is to encounter these dangers, receive compensation far greater than that awarded to the private citizen who undertakes to help others for no salary at all. It is an odd situation, indeed, that the benevolent citizen receives appropriate compensation for his goodness, while professional safety officers, who are paid to confront these hazards, receive a windfall. The firefighters and police officer, like Chadwick, should have been placed in the position they would have occupied had the injuries never occurred and nothing more. It is very curious that British courts ignore this fundamental principle of tort compensation that they themselves defined for the United States.

The same bases that apply to the cost-spreading rationale in the United States are relevant to Great Britain. Workers' compensation benefits, by allowing citizens to act as self-insurers, efficiently spread the costs of inevitable injuries to firefighters among the public rather than concentrating the loss on the individual. Additionally, firefighters are provided with outstanding pension opportunities, funded partially by the public, that give them the security of knowing that they will be able to retire with a steady stream of funds for years to come.

The allocation of the costs associated with all of these benefits among the public is the most appropriate way to provide for their availability. By allowing firefighters to recover both through these public means as well as in tort, British courts effectively undermine the efficacy of public selfinsuring and unjustly allow double recovery by firefighters. Allowing such recoveries places a heavy burden on the public who has tried to remedy these inevitable injuries in advance through public compensation systems. The 
public, as well as the integrity of the compensatory system, are much better served by allowing recovery only from the public compensation systems.

In summary, extending the Fireman's Rule to Great Britain is a workable and practical solution to ending the problem of firefighters recovering in tort for injuries caused by the inherent risks of firefighting. Under the sui generis theory, British citizens would be spared the burden of compensating firefighters for injuries that the citizens are, by law, powerless to prevent. Firefighters would still be allowed to recover for wanton or willful conduct that injures them and for the landowner's failure to warn of hidden dangers. Furthermore, assumption of risk properly bars recovery; British citizens should not be required to pay firefighters for injuries resulting from inherent risks that are voluntarily confronted. By recognizing these inherent risks and confronting them anyway, firefighters consent to injury and thereby relieve landowners of their duty of care. Finally, economic efficiency provides a sound basis for extending the Fireman's Rule to Great Britain. Firefighters are already compensated for encountering the inherent risks of the profession through workers' compensation and pensions. Allowing recovery both through these publicly-financed programs and in tort requires the British citizen to pay the firefighter twice for the same job. Allowing this double recovery by firefighters places an extreme financial burden on British citizens and results in a windfall to firefighters.

\section{CONCLUSION}

Since its creation in the late nineteenth century, the Fireman's Rule has become a fixture in American jurisprudence. It has been embraced almost unanimously by American jurisdictions and appears to be settled law for years to come. Although American courts are obviously persuaded by the efficacy of the Fireman's Rule, British courts have never embraced it. The following conclusions, however, demonstrate the need for Great Britain to begin employing the Rule.

First, British firefighters, like American firefighters, enter property by virtue of a legal right, and interference with the firefighters' operations after their arrival may result in liability on the part of the landowner. It is a great injustice for British law to remove the landowner's ability to exclude firefighters and then hold the landowner liable for injuries that the law renders him powerless to prevent. Application of the Fireman's Rule would protect British citizens from this legislatively-mandated powerlessness.

Assumption-of-risk theory also supports the application of the Fireman's Rule in Great Britain. Anyone of adult age must realize that firefighting poses inherent risks of structural collapse, smoke inhalation, burns, and heat injuries. It violates basic tort principles to allow firefighters to recover for injuries resulting from the dangers they have consented to encounter. Under assumption-of-risk theory, British citizens would be 
relieved of the burden of compensating injuries caused by risks inherent to firefighting. Furthermore, British firefighters could still recover for injuries caused by risks not inherent to firefighting. Assumption-of-risk theory, therefore, protects landowners from liability in tort without completely depriving firefighters of the chance to recover.

Finally, cost-spreading forms another rationale for extending the Fireman's Rule to Great Britain. The British public uses tax-based funding to provide compensation for firefighters. Allowing recovery beyond these modes of compensation results in double recovery for firefighters. The taxbased compensation system allows for low-cost, yet highly effective, compensation for firefighters. The costs associated with maintaining a fire service and compensating those individuals serving within it may be efficiently spread over the populous through tax-based funding.

All of these considerations lead to one conclusion: the most efficient, just, and beneficial approach to liability for injuries sustained by British firefighters from hazards inherent to their calling is to apply the Fireman's Rule. British firefighters should not be heard to complain about injuries resulting from the need for their services. Great Britain, for the sake of its citizenry and its justice system, should begin employing the Fireman's Rule.

Brandon K. Dreiman

* J.D. candidate, 1999, Indiana University School of Law-Indianapolis. The author served for six years as a firefighter in Knox County, Indiana, and as an EMT for four years in Knox County, Indiana, and for two years in Lawrence County, Illinois. The author thanks Jeffrey Waggoner, J.D. candidate, 1998, Indiana University School of Law-Indianapolis; Bernard Rudden, professor of comparative law, University of Oxford, and fellow of Brasenose College, Oxford; Julie Simpson, Personnel Department, London Fire and Civil Defence Authority; and his family, especially his brother, Eric, who is an Indianapolis Metropolitan firefighter, for all of their guidance and criticism throughout the development of this note. 